\title{
Notes
}

\section{LOVE'S LITIGATION: \\ PLATO'S PHAEDRUS AS TRIAL BY JURY}

\author{
SUSAN E. KINZ \\ INTRODUCTION
}

Under the shade of a wide plane tree, its blossoms fragrant and in full bloom, Socrates and his companion Phaedrus recline together. Barefoot, they have walked to this place from the walls of the city of Athens. They met earlier in the inorning and now it is noon, and the day is lot. The cicadas hum incessantly in the trees. The soft grass cushions their heads as they lay together; the cool water of the Illissus river snakes by their feet. Their discussion, as they recline, follows along their favorite topics: love and rlietoric. Their casual conversation murmurs like the water over the rocks, but their talk is more than just flirtatious chitchat; if brought back to the city, it could very well lay the foundation for philosopliy itself.

As they talk, Socrates tries to convince Phaedrus that rhetoric, the art of persuasion as applied in public lawsuits, is the same skill used in the persuasion of an individual in a very private matter:
Socrates: [W]ill not the science of thetoric as a whole be a kind of leading of the soul by means of things said ["logoi"], not only in law-courts and all other kinds of public gatherings, but in private ones too ....?
Phaedrus: No, I must say, not absolutely that: a science of speaking and writing is perhaps especially em- ployed in law suits, though also in public ad- dresses; I have not heard of any extension of it beyond that. ${ }^{1}$

1. PLATO, PHAEDRUS 261a\&-b5 (Christopher J. Rowe trans., 1986) [hereinafter PHAEDRUS]. The page numbers used throughout this Note to refer to Platonic texts are in accord with the Stephanus pagination systen. 
What are we, the readers, to make of this? Generally speaking, the Phaedrus is Plato's dialogue on love, human nature, and rhetoric. Composed entirely as a conversation between Socrates and Phaedrus, the dialogue shows Socrates' attempt to win Phaedrus' affections from Lysias, a rhetorician who recently captivated Phaedrus. Lysias had spent the early morning reciting a speech he had written, arguing to Phaedrus that a beloved, presumably such as Phaedrus, would benefit far more from the coinpany of a nonlover, such as Lysias, than froin that of a lover. ${ }^{2}$ The non-lover, a term whose meaning is explored in this Note, ${ }^{3}$ is Lysias' name for a companion who is purely rational, whose friendship with the beloved stems entirely froin logical and not emotional ties. The lover, Lysias had argued, is far too emotional and irrational to be of any real use to the beloved.

This is not a trivial speech that Lysias has written. The relationship between lover and beloved was of great political and social significance in ancient Athens. The lover was often seen as the beloved's introduction into the social and pohtical circles of the city. In return for sexual favors, the older lover would educate the younger, more attractive beloved in the pohtical, cultural, social, and intellectual matters of the day. ${ }^{4}$ In the character of the non-lover, Lysias had introduced a new type of companion for the beloved.

Phaedrus, coming across Socrates just outside the walls of the city, coyly tells Socrates of his morning and challenges the older man to better Lysias' argument. Taking up this dare, Socrates seductively leads Pliaedrus througl a conversation revolving around courts of law and love, souls and science, rhetoric and philosophy. He tempts Phaedrus with inyths great and fanciful; he offers scientific and logical proofs; he uses exanuples from the leading rlietoricians of the day; he pulls and tugs on emotions, displaying his own for greatest effect. He bests Lysias' argument both stylistically and substantively, arguing to Phaedrus that it is the lover, not the non-lover, who is the better companion.

2. See id. at $227 \mathrm{c}$.

3. See infra notes $98-116$ and accompanying text.

4. For a discussion of the significance of the homosexual relationship in ancient Athens, see Alexander Nehamas \& Paul Woodroff, Introduction to PLATO, SYMPOSIUM xiv-xv (Alexander Nehamas \& Paul Woodroff trans., 1989) [heremafter SYMPOSIUM]. 
Is Socrates' flirtation just that, or is there something else going on? Given the setting of the dialogue, its subject matter, and the privacy of the moment, one might conclude that Socrates' and Phaedrus' conversation is simply one of those moments where, as Socrates describes, rhetoric serves a solely private purpose. A closer look, however, reveals that precisely the opposite is the case. Contained within this private persuasion is a move of great political significance for Socrates. If Socrates can seduce Phaedrus with words of love in the countryside, then he will gain an ally in the city and, indeed, the city might be transformed imto that place where speeches can ascend to Truth. ${ }^{5}$

The political significance of the dialogue, despite its private content, is evident in three ways. ${ }^{6}$ First, at the beginning of the dialogue, we are told that Phaedrus has just spent the morning in the city listening to the rhetorician Lysias. ${ }^{7}$ Indeed, Phaedrus is carrying with him Lycias' speech. ${ }^{8}$ This oration, which argues the superiority of the non-lover over the lover, is itself a political act, aimed at furthering Lycias' political goals. ${ }^{9}$ With this speech in hand, Phaedrus is able to entice Socrates to leave the city and converse with him in the countryside, ${ }^{10}$ and it is this speech to which Socrates responds.

5. See infra notes 207-27 and accompanying text (discussing Socrates' myth of the soul and how the soul, through conversation, ascends to the Truth). Plato's theory of the Ideas, or Forms, is far too vast-and too controversial-to be considered at this time. Suffice it to say that, for Plato, the Ideas might be conceived as the reality behind (or above) our world, and whose appearance we mistakenly take for reality. See CHARLES L. GRISWOLd, .SELF-KNOWLEDGE IN PLATO'S PHAEDRUS 8 (1986). In this Note, words like Truth and Justice refer to this hyperuranian being beyond our world in "that which really is." PhaEdRuS, supra note 1 , at $247 \mathrm{~d}$.

6. The term "pohtical" is used here in its most literal sense. The word derives from "polis," the Greek word for "city." H.G. LIDDELL \& SCOTT, GREEK-ENGLISH LEXICON 654 (7th ed. 1991). Thus the term political is meant to portray both things of the city, as in the term "urban," and as the procedural basis for production in the city as in, "the city is moved by political means." The term is not meant to suggest politics in our modem sense of bipartisan government.

7. See PHAEDRUS, supra note 1 , at $227 \mathrm{a}$.

8. See id. at $228 \mathrm{~d}-\mathrm{e}$.

9. See infra notes $41-50,117-19$ and accompanying text (describing Lysias' pohtical aspirations).

10. See PHAEDRUS, supra note 1 , at $227 \mathrm{~b}-\mathrm{d}$. This fact is especially significant given that nowhere else in the Platonic corpus is the reader allowed such a detailed glimpse of setting, and Socrates admits to never leaving the city. For an enlightening discussion of the significance of the setting in the Phaedrus, see STANLEY ROSEN, THE QUARREL BETWEEN PHILOSOPHY AND POETRY 79-80, 85 (1993). 
Second, Socrates commands Phaedrus at the end of the dialogue to report their conversation back to Lysias. ${ }^{11}$ Thus, while the conversation itself takes place outside of the city walls, its origin and its destiny are clearly political. Socrates wants this conversation to have political import.

The location of their dialogue itself leads to the third and perhaps most important indication of the political significance of the dialogue: as they are walking along the river, looking for the proper place to rest and converse, Socrates tells Phaedrus that "the country places and the trees won't teacl me anything, as the people in the city will." ${ }^{\prime 12}$ Despite its tranquil beauty, the country cannot offer Socrates what the city can: the chance to learn and gain knowledge. ${ }^{13}$ Socrates' satisfaction from the conversation is not derived from the pleasant country setting; rather, it comes from a subsequent political utility. ${ }^{14}$ Thus, Socrates introduces the idea that even private persuasion can have political significance. As Socrates notes, the mode of persuasion is the same whether it takes place in a courtroom or outside; that is, the same science applies to both. ${ }^{15}$

This ancient observation is relevant for lawyers and litigants even today. Just as Socrates submits that private persuasion is similar to public persuasion, this Note submits that the persuasion of Phaedrus-and of individuals generally-is similar to the persuasion of a jury in a courtroom. Methods used to persuade one can be used to persuade many, and vice versa. Indeed, the Phaedrus can serve as a paradigm for a jury trial. By looking at a jury trial througl the context of a private persuasion, and by examining the interplay of relationships between the participants, we can perceive the dynamics of a jury trial, as well as its overarching systemic and societal purposes. While such a comparison will in no way offer itself as a practice manual for budding trial lawyers, it will show that some of the best techniques of persuasion in a trial are found in the persuasion used by Socrates in the Phaedrus; that the techmiques and strategies used to persuade an individual often can be the best techniques and strategies to persuade an entire jury. Such

\footnotetext{
11. See PHAEDRUS, supra note 1 , at $278 \mathrm{~b}-\mathrm{d}$.

12. Id. at $230 \mathrm{~d}$.

13. See id. at 230a.

14. See infra notes $39-40$ and accompanying text.

15. See supra text accompanying note 1 .
} 
a comparison will emphasize the practical necessity of knowing one's audience and will suggest that, for this reason, the process of voir dire may be the most important part of any trial. ${ }^{16}$

This comparison even hints at the possibility that the mode of conversation, as portrayed in the Phaedrus as a dialogue and as practiced in a trial, may be more important to society than the factual truths which such trials seek to discover. ${ }^{17}$ This Note explores the differences and similarities between the private persuasion of an individual and the public persuasion of a jury in an attempt to discover, or perhaps uncover, a characteristic of our jury system previously concealed. The jury system is often seen as a ineans to an end-Truth. This Note underscores the value of the jury system and the dialogues it nakes possible as an end in itself.

Throughout its many levels, the modern trial can itself be seen as a dialogue. Trials consist of questions and answers, arguments and counterarguments. Lawyers talk with chents, then tell jurors their chents' stories through conversations between lawyer and witness, and between lawyer and jury. ${ }^{18}$ Judges converse with jurors, telling them what is and is not admissible and instructing them on burdens and the relevant law; the jurors talk to each other in deciding the case. And if a case is appealed, the conversation takes place between lawyers and appellate judges and, then again, among the judges themselves. The judges write their opinions so that others inay benefit from the discussion. ${ }^{19}$ Law is made through conversation. That said, it must immediately be qualified: ideally, law should be made only through a proper conversation. The propriety of conversation lies not solely in its subject matter, though that is of course important. A proper conversation is also marked by its quality and style, its fluidity as it develops between listener and conversant. It is these elements of conversation that we can explore through Plato's Phaedrus.

16. See infra notes $86-97$ and accompanying text.

17. See infra Conclusion.

18. See Gerald B. Wetlaufer, Rhetoric and Its Denial in Legal Discourse, 76 VA. L. REV. $1545,1557-60$ (1990).

19. See id. at 1560-63. Wetlaufer notes that even judges engage in their own form of rhetoric. Having been persuaded of the correctness of a holding, and in a position to define the law, they write opinions so as to justify their decisions, using the strongest and most compelling arguments. The objective of judicial rhetoric is quite simple: to avoid appeal to a higher court. See id. 
To examine the elements of a proper conversation, we can imagine Socrates as a lawyer. $\mathrm{He}$ aims to persuade Phaedrus to accept the favors of the lover over the non-lover. For his own part, Phaedrus is at once a witness, subject to examination by Socrates, and a juror, who must choose between Socrates' argument and Lysias'. Lysias is the lawyer for the non-lover, or, alternatively, the prosecutor in a trial against the lover. The influence of the writer, Plato, is present as well. On the one hand, Plato is like a judge, presenting the evidence to a jury comprised of his readers so that they might reach some metaphilosophical conclusion. On the other hand, to the extent that Plato has a certain argument with which he himself wishes to persuade his audience, to the extent that he is not merely laying facts out for a jury to decide but actually creating a dialogue, he too is acting as a lawyer, presenting his own argument for judginent.

What is at stake? Literally, Love is on trial. But, as a selfproclaimed lover, ${ }^{20}$ so too is Socrates. ${ }^{21}$ While this may seem like a very private, or even trivial, controversy, it begins to take on great significance when Socrates argues that the lover is the human catalyst for experiencing Truth. ${ }^{22}$ The trial of the lover thus becomes monumental. We are observers of a contest between philosophy and rhetoric, and between Truth and appearance, in which the human soul is the prize.

\section{I. "Oyez! Oyez! All Rise, THIS COURT Is NOW IN SESSION"}

When parties enter a courtroom, they enter a world of formality and tradition. This was as true in ancient Greece as it is today. ${ }^{23}$ Socrates, however, has not taken Phaedrus to a court-

20. See infra notes $215-27$ and accompanying text.

21. Compare this analogy to Plato's Apology. In that dialogue, Socrates is arguing for his own life. See generally PLATO, APOLOGY, in FOUR TEXTS ON SOCRATES 63 (Thomas G. West \& Grace S. West trans., 1984) (describing Socrates' defense against the charges of impiety and corruption of the youth, offenses for which Socrates was condemned to death) [lereinafter APOLOGY]. Here in the Phaedrus, he is defending his nature as a lover. See infra Section IV.A. While Socrates' condemnation in the Apology marks his failure in the defense of his life, Socrates, as we shall see, is more successful in defense of his nature.

22. See infra notes 221-26 and accompanying text.

23. See APOLOGY, supra note 21, at 17a-19a. In the Apology, Socrates describes some of the formalities of the Athenian courtrooin, as well as his unfamiliarity with them. In his defense, Socrates tells the expectant jurors, 500 in number, that this is his first time in the courtroom and, as such, he is unfamiliar with its ways and the manners 
room, but rather outside the city and into the private realm of the countryside. The setting of the conversation is significant both as a tactical maneuver and as a substantive introduction to the subject matter. With the warm sun high overhead, the cicadas humming, and the soft grass underneath, Socrates makes sure that Phaedrus is relaxed and comfortable. Yet into this relaxed atmosphere, Socrates adds an imperative: their conversation must be substantive and inportant. To encourage such a conversation, Socrates tells Phaedrus a myth about the cicadas droning around them. ${ }^{24}$ The cicadas, as Socrates explains, were once a race of people. When given the gift of music, they were so enamored of it that they sang all day long, neglecting even to sleep or feed themselves. When soon they died, the Muses ${ }^{25}$ transformed thein into cicadas. ${ }^{26}$ But, as Socrates warns Phaedrus, the cicadas are not merely insects whose ceaseless humming entices their listeners into a state of quiet relaxation. Rather, they act as messengers, relaying the conversations they overhear to the Muses, who then judge the substantive quality of each discourse for appropriate reward to the conversants. ${ }^{27}$ Thus, if Socrates and Phaedrus are to impress the Muses, they must endeavor to inake their conversation as noteworthy as possible.

This particular setting is also significant in that there is a mythical history surrounding the area: Socrates and Phaedrus are resting near the site where, as the story is told, the young maiden Oreithuia was killed by the passionate advances of the North Wind Boreas. ${ }^{28}$ We are assured, however, that Phaedrus and Socrates are not actually resting upon the site of the maiden's demise; the actual site is farther down streain. ${ }^{29}$ According to the account, Oreithuia was playimg near the water with her companion Pharmaceia when Boreas, seemg her and becoming enamored,

of acting it requires. See id. at 17 a n.1, 17c-d.

24. See PHAEDRUS, supra note 1 , at $259 \mathrm{a}$-e.

25. "The Muses were nine in number, the daughters of Zeus and Mnemosyne, Memory. ... They are all ... of one mind, their hearts are set upon song and their spirit is free from care. He is happy whom the Muses love." EDITH HAMILTON, MYTHOLOGY 39 (1942) (quoting Hesiod's Theogony). Hamilton also quotes the Muses as having said to Hesiod: "We know how to speak false things that seem true, but we know, when we will, to utter true things."' Id. at 40.

26. See id.

27. See PHAEdRus, supra note 1 , at 2590 -d.

28. See id.

29. See id. at 229c. 
dashed her against the rocks and stole her away. ${ }^{30}$ This mythical depiction of a violent rape is the dialogue's first hint at the nature of the lover. The lover that it portrays is riotous, aggressive, deadly. ${ }^{31}$ Lysias, the prosecutor, argues against the lover for precisely this reason. The lover is unable to control his passionate, sometimes violent, nature. ${ }^{32}$ Socrates will need to convince Phaedrus that the lover offers much more than the violence represented in the myth of Oreithuia. Socrates will do this by telling Phaedrus that the lover has an integral role in the political and personal development of the beloved. ${ }^{33}$ To convince Pliaedrus, Socrates must first confront Lysias' attack on the intemperate and violent lover; he must impeach and redirect the image. Again, the setting is important. Socrates attempts, right from the very start, to place Phaedrus in a spot where he can view love with some detachment. $^{34}$ They are near the site of the dangerous love of Boreas, but not so near as to be threatened. Although distanced from the mythical situs of the violence of the lover, they are closer to it than they would be were they still in the city, where Love's violent nature has been castigated by the singularly rational Lysias. ${ }^{35}$

This venue change from the city to the countryside is Socrates' first stratagem in the persuasion of Phaedrus. By moving Phaedrus outside the city, Socrates can cure him of the spell cast

30. See id. at $229 \mathrm{~b}-\mathrm{d}$.

31. See also GRISWOLD, supra note 5, at 37 (discussing the "violence of eros" as a "central theme" in the dialogue concerning the story of Oreithuia and Boreas).

32. See, e.g., PHAEDRus, supra note 1 , at $231 \mathrm{~d}$ (noting that lovers "are sick rather than in their right mind, and that they know that they are out of their mind, but cannot control themselves"); id. at 233c (describing the lover as one who starts "violent hostilities because of small things").

33. See infra notes 221-26 and accompanying text.

34. This idea of detachment is one that is used throughout the Phaedrus. Socrates and Phaedrus are protected, for instance, from the warming yet dangerous heat and glare of the noonday sun by the plane tree ("ton platonos," see LIDDELI \& SCOTT, supra note 6 , at 644, iromically similar to Plato's own name) under which they repose. See PhAEDRus, supra note 1, at 229a-b. They must detach themselves from the lulling voice of the cicadas in order to accomplish the task at hand. See id. at 258e-259a. Moreover, the second half of the dialogue, a dry and techmical discussion of rhetoric standing in stark contrast to the sensual and intimate discussion of Eros in the first half, can be viewed as Socrates' attempt to untangle the philosophical benefits of love from its erotic dangers. Cf. ROSEN, supra note 10, at 79 (arguing that Socrates brought Pliaedrus to this warm, intoxicating site precisely to detach him from excessive sobriety with a tantalizing exploration of the maddening excesses of love.)

35. Cf. Plato, Republic, in The Collected dialogues of Plato 573b-92b (Edith Hamilton \& Huntington Cairns eds. \& Paul Shorey trans., 1985) (describing the tyrannical nature of Eros and, after so doing, expelling him from the ideal city). 
by Lysias. But to do so, Socrates must not only refute Lysias' interpretation of the evidence portraying the lover as violent and irrational, he must also reinterpret and transform that same evidence. As displayed by the myth, the lover's temper is the strongest argument against the lover. Socrates, however, will refashion the argument in favor of the lover, making the lover's weakness his advantage and showing Phaedrus that the lover's passion, when properly channelled, is not only useful, but essential. ${ }^{36}$

The lawyer in our society, however, cannot easily remove his witnesses or jurors froin the courtrooin and bring thein to a location in which his argument would be more persuasive. ${ }^{37}$ Nonetheless, a litigator can accomphish the same feat by mastering the art of storytelling. In his opening arguments to the jury, or with his foundational questions to a witness, the skillful litigator can weave the facts of the case into a setting; he can lift the jurors and witnesses from their seats and take them where he wishes them to be. He can maintain this effect by continuing to deepen his story as he develops his case, distancing his histeners from facts which may negatively influence thein while bringing thein to the leart of his argument. ${ }^{38}$ To this end, Socrates is a wonderful example for the trial lawyer; in the Phaedrus, Socrates shows himself to be a master of persuasive storytelling.

\section{THE PARTIES}

Lysias and Socrates are both attempting to seduce Phaedrus. Lysias tries to do so with his written speech. Socrates, on the other hand, does so with his mythical accounts of the human soul, characterizing the lover as essential to the beloved's pursuit of wisdom. There is an interesting twist to this seduction. Neither

36. See infra Section IV.A.

37. Courts are divided as to the issue of whether a jury view of a site can constitute evidence. See, e.g., McDowell v. Schuette, 610 S.W.2d 29, 31 (Mo. Ct. App. 1980) (allowing the jury to view the home of the defendant in a construction contract case but disallowing its use as evidence); Moore, Kelly \& Reddish, Inc. v. Shannondale, Inc., 165 S.E.2d 113, 119 (W. Va. 1968) (allowing the jury in a construction damages case to view the scene of the damage and to consider all pertinent physical facts as evidence, while disallowing as evidence any words spoken while the jury was on the site).

38. The skill involved here is not merely telling a story, but dramatizing it through the use of voice and expression. This dramatization will help the juror to reinember the details and facets of the argument. See EDWARD T. WRIGHT, WINNING COURTROOM STRATEGIES 180 (1994). 
Lysias nor Socrates desire Phaedrus for sexual reasons, ${ }^{39}$ but for political reasons, for the connection he can provide them to the social and political circles of Athens. ${ }^{40}$ But, interestingly, their pursuit of Phaedrus is nonetheless erotic and is itself centered around Love. To nnderstand their political ends, we must first understand their roles.

\section{A. For the Prosecution: Lysias}

As advocate for the non-lover, Lysias can be viewed as a prosecutor raising charges against the lover. His case against the lover has already been presented in the form of the written speech that he has read aloud and given to Pliaedrus. The charge he offers is that the lover is dangerous and irrational, and should be shunned. ${ }^{41}$

Lysias was not, however, a citizen of Athens. ${ }^{42}$ As a result, Lysias only rarely could speak for himself inside the Athenian courtrooin; ${ }^{43}$ for the most part, he wrote arguments on behalf of others. ${ }^{44}$ Lysias was in this essential way outside the political process. He had political power, but only in his position as an orator of fine repute. ${ }^{45}$

39. See GRIswoLD, supra note 5, at 46 (noting that Lysias' speech, while sexual in language, is missing any element of physical beauty and thus cannot be interpreted as aiming for a sexual effect).

40. See id. (suggesting that Socrates' conversation with Phaedrus is motivated for political reasons, that Socrates desires Phaedrus to be an intermediary between himself and all the important political figures in the city).

41. The threat of exile was a serious one in Athens. In the Apology, Socrates rejects exile as a possible punishment for his crime, and sarcastically renarks, "[n]oble mdeed would life be for me, a human being of my age, to go into exile and to live exchanging one city for another, always being driven out!" APOLOGY, supra note 21, at 91 The concept of identity and affiliation with one's city was crucial to the Greeks. People living in other cultures outside their own were considered barbarians, inferior in intellect and developinent. See C.M. BOWRA, THE GREEK EXPERIENCE 77 (1957).

42. See J.F. DOBSON, THE GREEK ORATORS 75 (1919).

43. While non-citizens were allowed to speak in the Athenian law court, their access was limited. See Douglas M. MACDOWELL, THE LAW IN CLASSICAL ATHENS 75-76 (1978). Indeed, records indicate that Lysias served as actual prosecutor only once. See DOBSON, supra note 42 , at 77.

44. See DoBSON, supra note 42 , at 77 .

45. It is interesting to note that both Lysias and Socrates are in effect outsiders to the pohitical machinery of Athens. Lysias is procedurally an outsider to the city but substantively an insider with great pohtical influence. $C f$. RONNA BURGER, PLATO'S PHAEDRUS: A DEFENSE OF A PHILOSOPHIC ART OF WRITING 9 (1980) (noting that, at the end of the dialogue, Socrates commands Phaedrus to repeat his words to the opinion-makers of the city, including Lysias). Socrates is procedurally an insider-a citi- 
Lysias wrote some 200 known speeches for the law courts of Athens during his life. ${ }^{46}$ As Plato surely knew, Lysias' forte was not his grand, magnificent or original writing style, but rather his ability to guide the style of his speech to fit the mouth of its intended orator. In the courts of Athens, each man was expected to defend himself. ${ }^{47}$ It was thus not unusual for an individual to hire soineone to write his apology. ${ }^{48}$ J.F. Dobson writes that "in order that the speech may seem appropriate to the speaker, it is necessary that not only his words and phrases but his sentiments should be consonant with his character. This effect Lysias attempted to produce, and he is credited with having attained great success." In his success, Lysias stands as the quintessential advocate, able to display all the rationale-and sentiment-behind the state's attack against the reckless, violent, anarchic lover. Here in the Phaedrus, Lysias adopts the posture that is crucial for every modern prosecutor: appearing to voice the fears of the community against the lawlessness of the accused. ${ }^{50}$

\section{B. For the Defense: Socrates}

On the other side of the bar, Socrates defends the lover. There are many descriptions of Socrates throughout the corpus of the Platonic dialogues: philosopher, ${ }^{51}$ midwife, ${ }^{52}$ teacher, ${ }^{53}$

zen-but nonetheless is an outsider because he is substantively feared and ostracized by his fellow citizens. See generally APOLOGY, supra note 21. As such, both characters must rely on the influence of others to achieve their political ambitions. In this light, their fight for Phaedrus can be seen as an ironic, but significant, twist on the lover-beloved relationship. While both cast themselves in the role of lover, or non-lover with a lover's desires in Lysias' case, their political need for Phaedrus is more akin to that of the beloved who needs the lover to introduce him into society. See supra text accompanying note 4.

46. See DoBson, supra note 42 , at 90 .

47. See APOLOGY, supra note 21 , at 17a n.1.

48. "Apologia" literally means "a speech in defence." LIDDELL \& SCOTT, supra note 6 , at 102 .

49. DOBSON, supra note 42, at 84; see also ROSEN, supra note 10, at 85-86 ("Lysias ... is a rhetorician and logographos, especially famous for his courtrooin speeches.").

50. Cf. Thuman W. Amold, Law Enforcement: An Attempt at Social Dissection, 42 YALE L.J. 1, 7-18 (1932) (commenting on how the theory of prosecutorial discretion seems to be at odds with the prosecutor's duty to enforce the law against criminals).

51. See, e.g., Plato, Phaedo 69d, in The Collected Dialogues of Plato, supra note 35 (Hugh Tredennick trans., 1954) (Socrates describing his endeavor to join the category of men who live the philosophical life).

52. See, e.g., Plato, Theaetetus $150 \mathrm{~b}-\mathrm{d}$ in The Collected Dialogues of PlaTO, supra note 35 (Francis M. Cornford trans., 1935) (Socrates characterizing himself as a 
friend, ${ }^{54}$ soldier, ${ }^{55}$ and enemy to the city. ${ }^{56}$ All are significant, but two characteristics are of particular importance in the Phaedrus. First, Socrates considers himself to be an erotic ${ }^{57}$ man, a lover. ${ }^{58}$ Indeed, Socrates' argument to Phaedrus in the Phaedrus assumes as its foundation that Socrates is erotic.

Second, Socrates is the inost intelligent man in Athens. In the Apology, Socrates quotes the oracle at Delphi, who declared that there was no one in Athens who was wiser than Socrates. ${ }^{59}$ Socrates' claim to wisdoin is that he is conscious of his ignorance. ${ }^{60} \mathrm{He}$ spends his day in the marketplace ["agora"], ${ }^{61}$ meet-

midwife, delivering the human soul to wisdom).

53. See, e.g., APOLOGY, supra note 21, at 19d-e (Socrates denying the assertion that he is a teacher because it implies that he received money for his conversations with the youth of Athens).

54. See GRISWOLD, supra note 5, at 26 (noting that Socrates and Phaedrus address each other as friends, albeit to varying degrees).

55. See, e.g., SYMPOSIUM, supra note 4, at 220d-e (Alcibiades describing Socrates' lueroics as a soldier).

56. See, e.g., ApologY, supra note 21, at 24c-25c (Socrates responding to the charge that he alone of all Athemians corrupts their youth).

57. The tern "erotic" is not used here in its modern, everyday sense, though that sense is a part of its definition. Rather, "erotic" refers to that which is moved by the power of, or is sensitive to the power of, Eros. Generally speaking, there are two dialogues that focus on Eros and the erotic nature: the Phaedrus and the Symposium. A third dialogue could be added if one counts the Republic, in which Eros, a tyrant, is cast out of the ideal city. In the Symposium, Socrates describes Eros as a "daimonion," or "daimon." See SYMPOSIUM, supra note 4, at 202e-03b. A daimon, defined as a demon or inferior being, is not quite a god, but not a human either. As Socrates describes him, Eros was seen as a messenger between the gods and man. Halfway between the immortal and mortal, the beautiful and ugly, the good and bad, the desire created by the messenger Eros moved man toward knowledge, first of things which he could experience and then of things beyond his experience. See id. at 202e-212c. Thus, as portrayed by Socrates, the lover or erotic individual is one who is moved by Eros towards the Truth.

58. Socrates' self-characterization as a lover is explored, infra text accompanying notes 213-27. Compare this view of Socrates with the portrayal of the philosopleer in the Symposium, where Alcibiades accuses Socrates of being, far from erotic, a cold and uncaring man, insensitive to the youth's passionate advances. See SYMPOSIUM, supra note 4, at $215 \mathrm{~b}-19 \mathrm{~d}$. Socrates, were he to respond, would counter Alcibiades' charge by arguing that he has moved beyond the simple love of human beings to a love of knowledge. See id. at 211b-12b (describing the ascent of Love from love of beautiful bodies to the love of absolute Beauty and true Virtue).

59. See APOLOGY, supra note 21, at 20d-21a. In the Apology, Socrates calls upon the oracle to explain the reasons behind the philosophers' incessant questioning of people's alleged wisdom. As Socrates explains, he is always challenging the wisdom of others in order to prove or disprove the oracle's statement; since he hasn't yet disproved it, he inust indeed be the wisest man in Athens. See id. at 21b-23b.

60. See id. at $21 \mathrm{~d}$.

61. "Agora" can also be translated roughly to mean "place of assembly." LIDDELL \& 
ing with youths and adults, questioning their beliefs and guiding (or arguably, goading) them to the realization that they did not know what they thought they knew. ${ }^{62}$

This quest for self-knowledge is a central theme of the Phaedrus. In the beginning of the dialogue, Socrates claims that he is forever striving to know the nature of his self. ${ }^{63} \mathrm{He}$ questions whether his nature is complex and violent like that of the horrendous beast, Typhon. ${ }^{64}$ Described as the father of the winds, ${ }^{65}$ Typhon was "[a] flaming monster with a hundred heads, [w]ho rose up against all the gods. Death whistled from his fearful jaws, [h] is eyes flashed glaring fire."

Whether Socrates is like Typhon is crucial to his persuasion of Phaedrus on two levels. By questioning whether he himself is violent and complex, Socrates very carefully identifies himself with the lover. ${ }^{67}$ With this identification, Socrates is demonstrating empathy for the lover, his chent. Just as it is important for a jury to see that a litigator believes in the story of his client, ${ }^{68}$ so too must Pliaedrus see that Socrates believes in the story of the lover.

On another level, just as Socrates must confront and overcome the accusation that the lover is violent and dangerous, so too must he confront and defeat his own reputation. A lawyer will never win his case if he cannot establish his own credibility before the jury. ${ }^{69}$ If a jury is to believe a litigator, it must feel that the litigator is honest, trustworthy, companionable even. Socrates' reputation as an insurgent was well-known in Athens. ${ }^{70}$ Phaedrus

SCOTT, supra note 6 , at 7. It was the arena in which the men of Athens spent their day, engaging in public and political conversation. See id. It is interesting to note, however, that it was considered somewhat disreputable or vulgar to simply lounge in the agora. See id.

62. See Apology, supra note 21, at $23 \mathrm{~b}$.

63. See PHAEDRUS, supra note 1 , at 230a.

64. See id. at 230a4-6. The importance of the Typhon analogy appears later, when Socrates describes the complex nature of the soul. See notes $166-86$ and accompanying text. There it will be seen that, while the soul is indeed complex, the question remains as to whether an individual can properly control the differing facets of the soul.

65. See LIDDELI \& SCOTT, supra note 6, at 825.

66. HAMmLON, supra note 25 , at 83 (translating from Hesiod's Theogony). Typhon was destroyed by a lightning bolt thrown by Zeus in the latter's quest for kingship over all the gods. See id.

67. See infra notes $213-27$ and accompanying text.

68. See WRIGHT, supra note 38 , at 3 .

69. See, e.g., id., at $174-76$ (recommending strategies for developing credibility to the jury during a lawyer's opening statements).

70. Socrates was eventually executed for this insurgence. See generally APOLOGY, 
has also heard tales in which Socrates rebuffs the amorous advances of beautiful beloveds. ${ }^{71}$ Unless Phaedrus feels comfortable with Socrates' nature and with Socrates' public quest for self-knowledge, he will never believe Socrates' argument.

\section{The Witness and Juror: Phaedrus}

The last participant in the trial is perhaps the inost important: Phaedrus. Phaedrus is the character with whom the reader most identifies. While Phaedrus is treated procedurally as a witness, he is, in substance, the juror of the dialogue. As witness, he is subject to cross-examination by Socrates. ${ }^{72}$ As juror, Phaedrus is called upon to decide which argument is best. Although Lysias and Socrates are argumg the substantive inerits of the non-lover and the lover, Phaedrus is judging them on the style of their arguments. ${ }^{73}$ This mirrors a general truth about jurors: they often base their decisions, at least in part, on their own interests and knowledge, not on the substantive matter at issue. ${ }^{74}$ Importantly, Lysias and Socrates are both aware of this psychology and they adopt strategies to capitalize on it. That is, they know what they need to say, and how they need to say it, in order to persuade Phaedrus. Victory will be awarded to the advocate who can best discern and control Phaedrus' own self-oriented and selfish interests.

supra note 21 , at $35 \mathrm{~d}$ (Socrates' trial and condemnation); PHAEDO, supra note 51 , at 117-18 (Socrates' execution).

71. See, e.g., SYMPOSIUM, supra note 4, at 215b-22c (Alcibiades' tale of Socrates' rejection of his erotic advances).

72. See infra Section III.B and accompanying text. Lysias is unable to cross the witness because he is represented only by his written document. See PHAEDRUS, supra note 1 , at $228 d$.

73. See PhaEdrus, supra note 1 , at $234 \mathrm{c}-\mathrm{b}$. Phaedrus compliments Lysias, claiming that he did not think that "any other Greek would have different things from these to say, which were weightier and more in number, about the same matter." Id. at 234e. To move Phaedrus from a discussion of appearance to one of substance will be Socrates' greatest obstacle. See also ROSEN, supra note 10, at 84-85 (discussing the difference between Phaedrus' love for speeches, which is passive interest only in style, and Socrates' love for speeches, which is active interest in the pursuit of Truth).

74. See Donald E. Vinson, JuRy Persuasion: Psychological Strategies and TRIAL TECHNIQUES 114-15 (1993); see also WRIGHT, supra note 38, at 11-12 (suggesting that advocates pick jurors who have the belief system necessary to side with their client). Cf. MACDOWELI, supra note 43, at 52 (writing of an Athenian jury's verdict in favor of the rletorician Demosthenes, "It was hard to persuade an Athenian jury to give more weight to the rules of law than to the personalities involved in a case"). 
Phaedrus is known in Athens to be a devotee of rhetoric. Charles Griswold writes of Phaedrus:

[He is] a cultured dabbler in rletoric, materialistic pliysics, and medicine. He has a fondness for avant-garde literary movements ... for cleverness and novelty, for liedonism, utilitarianism ... and materialism. His morals are undoubtedly very permissive. I imagine him as a devotee of liealth fads and gatherings of fashionable literati. ${ }^{75}$

Phaedrus loves rhetoric for its beauty and he is impressed by the styles of various rhetoricians. ${ }^{76}$ Fortunately for Socrates, he is aware of Phaedrus' preoccupation with rhetorical style, and is able to inanipulate it. Socrates dedicates his first speech on Eros in the Phaedrus to the title character and proceeds to flatter him:

You've a superhuman capacity when it comes to speecles, Pliaedrus; you're simply amazing. Of the speecles which there have been during your lifetime, I think that no one has brought more into existence than you, either by making them yourself or by forcing others to make them, in one way or another. ${ }^{7}$

Phaedrus also serves to connect the dialogue in the Phaedrus to another, earlier dialogue, the Symposium..$^{78}$ In the Symposium, Phaedrus is called "the father of the logos."79 Indeed, it is Phaedrus' coinplaint in the Symposium that nothing is ever spoken of the god Eros that initiates the great discussion on Eros' character. $^{80}$

75. GRISWOLD, supra note 5 , at 25 .

76. See id. at 22; PHAEDRUS, supra note 1, at 266c-67e (Socrates' and Phaedrus' summing up the styles of the rhetoricians of the day).

77. PHAEDRUS, supra note 1 , at $242 \mathrm{a}-\mathrm{b}$.

78. In a similar manner, Lysias indirectly connects the Phaedrus with yet a third dialogue, the Republic. In the Republic, Socrates converses with Cephalus, Lysias' father. See generally REPUBLIC, supra note 35, at 328b; see also ROSEN, supra note 10, at $85-86$, (noting Lysias' role in connecting the Phaedrus with the Republic).

79. SYMPOSIUM, supra note 4, at 177d5. "Logos," one of the most important concepts in Greek philosophy, can be translated in many different ways, including "word," or "expression," of inward thought or the thought itself. LIDDELL \& SCOTT, supra note 6, at 476-77. More generally, it can mean "speech," "narrative," or even "language." Id. It also carries the logical, technical meanings of "ratio," "account," or "analogy." Id. In this context, it is most likely meant to suggest that Phaedrus, as the "father of the logos," is the creator of many speeches.

80. Presumably, it is of this discussion that Phaedrus-in the Phaedrus-reminds Socrates with his remark: "[Lysias' speech] will be quite appropriate for you to hear, because the speech (logos) on which we [Phaedrus and Lysias] were spending our tine was, 
In the Symposium, Phaedrus' speech characterizes an Eros who is superficial and atheistic, ${ }^{81}$ and demonstrates that Phaedrus cares more for the utility of love than for its passions. ${ }^{82}$ His choice of lover and frequent compamion, the doctor Eryximachus, ${ }^{83}$ indicates that, for Phaedrus, love is only important insofar as it serves some purpose to its intended. ${ }^{84}$ This is important to keep in mind as the arguments for each side are presented; for, as Socrates' seduction of Phaedrus will demonstrate, ${ }^{85}$ the most important piece of knowledge for a successful persuasion is knowledge of one's audience.

Thus does Plato introduce the characters for the trial of the lover. But there is one critical difference between the dialogue and a modern jury trial. In a real trial, the litigators would have an opportunity to examine the juror through the process of voir dire. ${ }^{86}$ Literally, "to see to speak," voir dire is the only process through which an advocate can converse directly with the members of the jury. ${ }^{87}$ It is the only opportunity to learn the individual quirks and interests of each juror and to lave some control over who will decide the case. ${ }^{88}$ Such knowledge and control are essential consequences of voir dire. " $[N]$ one comes to the courtroom with his or her mind as a blank slate. All jurors possess preexisting attitudes, beliefs, experiences, and knowledge. This must imevitably affect, to some degree, however small, the ways in which jurors will judge a case. . . . [A]11 jurors are biased." ${ }^{89}$ Also important, this opportunity for conversation is crucial to establisl-

I tell you, in a certain sort of way about love." PHAEDRus, supra note 1, at 10c.

81. See SYMPOSIUM, supra note 4 , at $179 \mathrm{~b}-\mathrm{d}$.

82. See Stanley Rosen, Plato's SYMPOSIUM 50-51 (1987); see also Rosen, supra note 10, at 39-59; BURGER, supra note 45 , at 10-11.

83. See, e.g., SYMPOSIUM, supra note 4, at 176b-78a (depicting Phaedrus and Eryximachus as attending Agathon's celebratory banquet together and flirting with each other throughout the dialogue's opening passages).

84. See BURGER, supra note 45 , at 10 (implying that Phaedrus' actions are completely self-centered).

85. Cf. infra notes 216-19 and accompanying text (exploring Socrates' attempts to have Phaedrus identify himself with Socrates). In order to move Phaedrus, Socrates must flrst know who Phaedrus is and what his interests are. See supra text accompanying notes 75-77.

86. See John N. IANNUZZI, TRIAL: Strategy and PSychology 120-21 (1992).

87. See id.

88. See id.

89. VINSON; supra note 74 , at 114. 
ing a relationship of trust and confidence between litigator and juror. ${ }^{90}$ Without this trust, there can be no persuasion.

There is no pre-trial voir dire in the Phaedrus. ${ }^{91}$ Instead, Lysias and Socrates inust rely on their previously-gained knowledge of Phaedrus. ${ }^{22}$ But they are lucky. While they did not formally choose Phaedrus as their juror ${ }^{93}$ they both know him. They know who he is, who his friends are, what his interests are, how he sees the world. They know he is interested in both rhetoric and discussions of Love. In fact, had they been able to pick a juror to hear their case, they could hardly have selected a better individual. ${ }^{94}$

Of course, in inodern jury trials, such information as Lysias and Socrates have concerning Phaedrus is as simple to obtain as a deinographic study. Litigators can hire pre-trial experts and analysts to research what types of imdividuals feel which way about whatever circumstances fit the nature of their case..$^{95}$ This information, coupled with a few well-tailored questions during voir dire,

90. See id. at 111; WRIGHT, supra note 38, at 27 ("Jurors who participate in the voir dire are more likely to listen during the trial and to participate in the discussion during jury deliberation.").

91. But see infra Section III.B (questioning by Socrates takes form of both crossexamination and a modified voir dire).

92. There is textual evidence to support their knowledge of Phaedrus' interests. Lysias begins his speech to Phaedrus witl the phrase "You know how matters are with me." PHAEdRus, supra note 1 , at $230 \mathrm{e}$. This indirectly indicates that Lysias has knowledge of Phaedrus' interests, at least enough to know what Phaedrus knows of Lysias. Socrates likewise is familiar with Phaedrus' interests. Socrates conversed with Phaedrus on this very same subject, Love, in the Symposium, see generally SYMPOSIUM, supra note 4 (portraying Socrates and Phaedrus as both attending the syinposium on Love held at Agathon's house), and, assuming that the Phaedrus took place following the Symposium, see GRIswOLD, supra note 5, at 19, then we can expect that Socrates knows very well Phaedrus' impression of Love.

93. Indeed, it was Phaedrus who enticed Socrates to talk, not the other way around. Phaedrus encouraged Socrates to reply to Lysias' remarks, knowing that the remarks would enflame him. See PHAEDRus, supra note 1, at 227c. Also, even though he may or may not have initiated the conversation with Lysias, Phaedrus purportedly asked him to repeat it several times. See id. at 228a.

94. It should not go without mention that Plato is not as fortuitous as Socrates or Lysias in his control over the recipients and judges of his arguments. By offering his argument in written form, Plato has no control over who reads his argument and what opinions are formed regarding it. See infra Part V.

95. See WRIGHT, supra note 38, at 133-36; see also JoHN A. JENKINS, THE LITIGATORS: INSIDE THE POWERFUL WORLD OF AMERICA'S HIGH STAKES TRIAL LAWYERS 327-33 (1989) (noting the reliance of a highly successful plaintiff's attomey, Philip Corboy, on a market research survey to determine the "type" of juror that would award a large judginent in a particular case). 
can aid a hitigator immensely in picking a sympathetic jury. While not an exact science, these demographic studies go a long way to telling the hitigators what they need to know about their potential jurors. ${ }^{96}$

The process of voir dire indirectly serves to link a party with his community. The Umited States Constitution has been interpreted generally to grant an individual the right to a jury of one's peers. ${ }^{97}$ This interpretation implies a sense of commumity, a behef that a case should be judged by people who find themselves in the same community as the parties involved in the trial. However, given our quest for fairness and impartiality in a jury, we have moved somewhat beyond this sense of community. In our world, actual or personal knowledge of either one of the parties in a trial, or their attorney or witnesses for that matter, is grounds for dismissal. Voir dire alone rennams as a link to the idea of community. It alone allows the parties in a trial to know who is hearing their case. As such, it offers an element of control and predictability in an otherwise largely uncontrollable and unpredictable process of fact-determination.

\section{THE PRosecution}

\section{A. The State's Case Against the Intemperance of the Lover}

As prosecutor, Lysias carries the burden of convincing Phaedrus that the lover is a dangerous individual. His polemic is structured as a comparison between the lover and the non-lover, and between the benefits each can offer the beloved. Lysias' basic argument is that the non-lover is a better companion because, unlike the lover, the non-lover has only the best interests of the beloved in mind. ${ }^{98}$ The non-lover wishes the beloved to achieve his best, while the lover, sickened with desire, seeks only to consune the beloved..$^{9}$

96. See JENKnNs, supra note 95, at 327-33 (observing how Corboy's use of a market survey helped him pick a jury that, if the case had not settled, was disposed to award between $\$ 3$ and $\$ 5$ million).

97. See U.S. CoNST. amends. VI, VII; see also Duncan v. State of Louisiana, 391 U.S. 145, 149 (1967) (applying, through the Fourteenth Amendment, the Sixth Amendment right to a jury trial to state criminal trials because "trial by jury in criminal cases is fundamental to the American scheme of justice").

98. See PHAEDRUS, supra note 1, at 231b-c, 232d, 234b.

99. See id. at $234 a-b$. 
To support his thesis, Lysias points to readily observable facts. He begins by attacking the lover's inability to control himself or his emotions in any area in which his beloved is concerned. ${ }^{100}$ He tells Phaedrus that the lover's nature is selfish and fickle; he will soineday regret everything that he did for the beloved. ${ }^{101}$ The non-lover, however, is always in control of his emotions and, as such, is inuch more capable of providing a reliably satisfactory relationship. ${ }^{102}$

Lysias is also particularly caustic about the effect that a beloved's relationship with his lover will have in the public arena. Lovers are braggarts; carelessly, they will announce their conquest to anyone. ${ }^{103}$ People who witness a lover and his beloved conversing in public will immediately think that they are discussing their passion for each other. ${ }^{104}$ The lover is needy of affection, and, moreover, is a jealous companion. He will force a beloved to break off all social contacts, including those contacts that may be beneficial to the beloved's career. ${ }^{105}$

The non-lover is none of these things. He does not need affection; rather, he deserves it. ${ }^{106}$ The non-lover will be much inore useful and publicly beneficial to the beloved. The non-lover will keep the relationship private, and can be seen with the beloved in public without censure. ${ }^{107} \mathrm{~A}$ non-lover wishes only the best for his beloved, including prominent and influential social contact. ${ }^{108}$ While the lover is interested only in bodily pleasures, the non-lover is interested in friendship and the pursuit of intellectual pleasures. ${ }^{109}$ The non-lover will also speak truthfully to the beloved; this truthfulness will allow the beloved to better himself. ${ }^{110}$ And, of course, there are more non-lovers than lovers

\footnotetext{
100. See id. at $231 \mathrm{~d}$.

101. See id. at 231a, 231b-d.

102. See id. at $232 \mathrm{a}$.

103. See id. at 232a.

104. See id. at $232 \mathrm{a}-\mathrm{b}$.

105. See id. at $232 \mathrm{c}$.

106. See id. at $233 \mathrm{~d}-\mathrm{e}$.

107. See id. at 232a-b.

108. See id. at 232c-e.

109. See id. at 232e-33a.

110. See id. at 233a-d. Curiously, while Lysias directly accuses the lover of not telling the truth (either for fear of being disliked or as a result of his passion), he does not directly state that the non-lover will only tell the truth. Rather, he likens the non-lover to 'trustworthy' friends and family to whom the beloved can tum. See id. at 233c-d.
} 
from which the beloved can choose. ${ }^{111}$

Lysias' argument to Phaedrus is a strange one indeed. On its face, it seems to contradict itself. Lysias is arguing that Phaedrus should give himself to a non-lover because a non-lover is not swayed by the passion of Eros. But, if that is the case, then the non-lover should not be at all interested in the affections of the beloved.

What does Lysias want? Lysias is asking Phaedrus, the beloved, to accept the advances of the non-lover-presumably Lysias himself-yet he purposefully conceals any passion the non-lover might feel toward the beloved. Perhaps he is trying to woo Phaedrus subtly, fearful that an open flirtation might chase away his prey. But Phaedrus is not shy. Nor is he young ${ }^{112}$ or inexperienced. $^{113}$ Phaedrus is both self-centered and utilitarian. ${ }^{114} \mathrm{He}$ wants only those things that will benefit him. Knowing this, Lysias must be slanting his argument so as to appeal to Phaedrus' utilitarian ways. Phaedrus is concerned about advancing his role in society; he wants to move in the right circles and have the right things said about him. Lysias' argument for the non-lover plays to Phaedrus' pohitical desires.

But why should Lysias portray himself as a non-lover? Lysias could simply have said that he, not Socrates nor any other person, was the right lover for Phaedrus. Instead, Lysias wants to specifically distance his position froin that of the lover. In an essential sense, the lover's position is too focused for Lysias. The lover is concentrated solely on the beloved and his relationship with this individual. Lysias has broader goals in mind and the character of the non-lover is more in tune with these broader goals. That is to

111. See id. at $231 \mathrm{~d}-\mathrm{e}$.

112. See GRISwOLD, supra note 5, at 21 (noting that Phaedrus, while younger than Socrates, is more middle-aged than youthful at the time of the dialogue).

113. See supra note 85 and accompanying text (explaining that, in the Symposium, Phaedrus is the beloved of Eryximachus).

114. For instance, it is suggested that Phaedrus chose as a lover a doctor so that he could enjoy the practical benefits of the attentions of a man of medicine. See ROSEN, supra note 82 , at 26 .

Still more specifically, Phaedrus conceives the good effects of Eros as utility to the beloved. . . . What Phaedrus means by "good" may be shown in a literal, and therefore awkward, translation of his next sentence: "For I cannot name a greater good .... from his earliest youth than a useful lover . . . and a sweetheart to the lover." ... Phaedrus' first thought is for what benefits the beloved; his elliptical language betrays the degree of his selfishness.

Id. at 50-51 (citations omitted.) 
say, Lysias wants to appeal to a wide audience. It is true that Lysias gave this speech to Phaedrus earlier this morning, but the speech does not contain a single reference to any particular individual, and can be directed to any number of different individuals. But Lysias, a master rhetorician, knows that in order to persuade even a large group he must at soine level assert familiarity with each of them. ${ }^{115}$ Each individual who will hear his speech has varying tastes, skills, and interests, and Lysias cannot possibly stroke the vanity or understand the perspective of every member of his extended audience. So, to strike the necessary chord of familiarity, he encourages the unnanied individuals to associate themselves with him. Rather than asserting his familiarity with the audience, he appeals to their familiarity with him. He begins his address: "You know how matters are with me ...."116 Thus each person whoin Lysias addresses is encouraged to consider Lysias as someone they know, soineone to whoin they can relate, someone who has taken them into his confidences and is encouraging them now to do the same.

In this sense, Lysias is also a politician, and his praise of the non-lover is his campaign for personal acceptance. ${ }^{117}$ " $[\mathrm{T}]$ he nonlover who cannot speak to any particular individual inust represent, it seems, the politician who woos the many as one, offering his services in the interests of the people ["demos"]."118 Lysias cannot allow himself to be openly erotic towards any one individual; he must attend to everyone. He cannot afford to be passionate; there are too many varying and conflicting interests at stake. To be sure, Lysias wants Phaedrus on his side. But he also wants the affection of an entire city. ${ }^{119}$ And in order to gain that affection, he must appeal to the interests common to all.

115. This assertion of familiarity, of identification, is the primary tool for establishing a lawyer's credibility before the jury. Cf. WRIGHT, supra note 38 , at $2-4$ (providing examples for ways in which a lawyer can "sell" himself to the jury).

116. PHAEDRUS, supra note 1 , at $230 \mathrm{e}$.

117. See BURGER, supra note 45 , at $19-30$.

118. BURGER, supra note 45 , at 19 . The non-lover thus looks to public opinion, not individual passion, to satisfy his desires. See id. His pursuit is open and public, so his advances are limited to those that will be accepted by society.

119. We should remember that Lysias never addresses Phaedrus directly. His written speech is an address to any person who "knows how matters are" with him. See PHAEDRUS, supra note 1 , at $230 \mathrm{e}$. 
Lysias'. position demonstrates precisely the problem of any advocate faced with a jury of individuals with varied interests. ${ }^{120}$ The advocate must find a way to reach each individual on some personal level. To accomphish this task, Lysias has decided to appeal to the non-erotic, rational interests that guide the everyday actions of most individuals. He tries to appeal to every one, and he wishes to offend no one. Whether this stratagem works can only be judged in light of how the jury reacts. In the Phaedrus, the juror is clearly not satisfied. ${ }^{121}$

A related issue arises because Lysias chose to write his speech and give a copy to Phaedrus. ${ }^{122}$ Lysias seemingly has chosen this medium of argument because he wants as inany people as possible to hear his argument. By handing Phaedrus a copy of his speech, he is assured that others will also hear his speech. He knows that Phaedrus, given his character and love of rhetoric, ${ }^{123}$ will relay that speech to others. In so doing, Phaedrus will laud not only the attributes of the speech, but also both its subject matter and its author. Moreover, the written word is quickly distributed and argues its case even when its author is not present-as such, it is the easiest way to reach the largest audience.

But there are dangers attendant upon the use of a written argument. ${ }^{124}$ Foremost is the risk that the argument will be misunderstood or misapphed. This is particularly the case when the author is not present to defend and clarify her argument. Reflecting a concern for these problems, our trial system relies on oral argument, as was the tradition in ancient Greece. ${ }^{125}$ Lawyers tell their chent's story through conversations with witnesses. Jurors are swayed as inuch by the tone of this conversation as by the facts that are presented. Their judgment of a witness' credibility, for instance, is determined by the witnesses' demeanor and appeal in

120. See infra Section IV.B.

121. See infra note 140 and accompanying text.

122. See PHAEDRUS, supra note 1 , at $228 \mathrm{~d}-\mathrm{e}$. Lysias' decision to write his speech will be of great significance later in the dialogue when Socrates attacks the persuasive capacity of the written word. See infra notes $242-48$ and accompanying text.

123. See supra Section II.C.

124. For a more complete discussion of the dangers of the written, versus oral, argument, see infra notes 242-48 and accompanying text.

125. Cf. MACDoweLL, supra note 43, at 249-51 (demonstrating traditional oral argument in Greece, but noting the differences from the modern American trial system in strict time limits and mandatory litigant speeches). 
answering questions. ${ }^{126} \mathrm{We}$ believe that there is truth in oral conversation. Even in an appeal, in which the appellate court is examining the written record to review the lower court's decisions, it does not devalue or negate the jury's findings as to the facts of the case. There is a very strong presumption that what the jury determines based on its face-to-face encounter with the parties and their stories is more certam than any determination that could be based solely on a written record. ${ }^{127}$

Its written form aside, there are styhistic and substantive probleins with Lysias' argument. Such problems would work against an advocate's persuasion of a jury. While Lysias does seek empathy from his audience, ${ }^{128}$ he undercuts the strength of this tactic with an argument that is detached and formal. Rather than drawing the audience to him with a description of the non-lover as a brave, wonderful, essential character, he merely describes the non-lover's attributes as if conducting an inventory of machinery. ${ }^{129}$ It could be said that Lysias is forced into this position because he argues that the non-lover is rational while the lover is passionate and unstable. In an exposition of the virtues of the non-lover, Lysias might feel constramed to exhibit no enotion himself. However, to be persuasive, Lysias should have tried to bring out the liuman side of the non-lover, perhaps by einphasizing the friendship and compassion the non-lover could offer the beloved. ${ }^{130}$ Instead, he cliose to be rational .... and unpassionate.

Despite its rational appearance, moreover, Lysias' story is

126. See IANNUZZI, supra note 86 , at $72-73$.

127. See U.S. CONST. amend. VII (". . . no fact tried by jury, shall be otherwise reexamined in any Court of the United States, than according to the rules of the common law."). The standard for appellate review of jury fact-determinations is referred to as the "sufficiency of the evidence" standard. Under this standard, the jury determination must be upheld unless the appellate court finds that the facts are such that a reasonable man could not have arrived at the same conclusion as the jury. See, e.g., Western Co. of North America v. United States, 699 F.2d 264, 276 (5th Cir. 1983).

128. See supra text accompanying note 123.

129. See supra text accompanying notes 100-11.

130. A lawyer knows that he must be able to nuake even a large corporation seem human and vulnerable, and that such a portrayal may be the only way his chient can win the sympathy of the jury. Cf. Overton A. Currie \& Ronald G. Robey, Winning Stratgies in Construction Negotiations, Arbitration, and Litigation 308 PLI/REAL 911, 971 (1988) (encouraging lawyers defending construction corporations to find witnesses who are wellversed in the matter and who have a "good appearance, demeanor, and the ability to inspire trust and confidence"). 
mternally inconsistent. ${ }^{131}$ As such, it is doomed to be less than wholly persuasive. Trial strategists recommend that a lawyer inust always present a story that is not only logical, but is based on an interpretation of facts that is not itself contradictory. ${ }^{132}$ The lawyer should pick a theme that explains each and every fact in a cohesive, plausible manner. Lysias has indeed given several plausible reasons why a non-lover might nake a better compamion for the beloved. ${ }^{133}$ But he has premised this argument on the inconsistent assumption that a non-lover is erotically interested in the beloved, ${ }^{134}$ even as he argues that the non-lover is interested not in such sexual favors but only in benefitting the career of the beloved. ${ }^{135}$ While Lysias may have chosen this argument for valid political reasons, its inconsistency is easily recognized and very hard to dismiss.

The greatest fault of his argument, however, may be Lysias' failure to tell a coinpelling story. John Iannuzzi compares the persuasion of a jury in a trial to a legal dranatic presentation:

Each time you read a book, each time you see a motion picture, you are subjected to a dramatic presentation that works toward an end-hopefully entertainment or enlightenment. If the presentation is drab or dull, you quickly lose interest, close down your mind, close the book, walk out of the movie, or just sit there bored, enduring, anxious to get out. ${ }^{136}$

Lysias is like a logical, but boring, trial lawyer. He has rational reasoning, black and white photographs, two-dimensional graphs. But his theory has no passion, no drama, no edge-of-your-seat excitement. Dobson notes that Lysias "seldoin employs theatrical effects for the purpose of overpowering the feelings of the court. $\mathrm{He}$ trusts more to logic than to the elements of pity and ter-

131. See GRISwOLD, supra note 5, at 48-50.

132. See IANNUZZI, supra note 86, at 2 ("Each [fact] must be laid into the framework of the trial, so that at the end, ... the advocate can call upon each of the [facts] to weave together a fabric of irresistible strength and logic to carry the day for his or her chent."); Steven LuBET, MODERN TRIal ADVocacy: ANalysis and PRactice 8 (1993) ("The facts upon which your theory is based should reinforce (and never contradict) each other.").

133. See supra notes 100-11 and accompanying text.

134. And moreover, Lysias assumes that a beloved who is by nature erotic would be attracted by the cold disinterested advances of the non-lover. See GRIswoLD, supra note 5 , at $48-50$.

135. See PHAEdrus, supra note 1 , at 231a-234c.

136. IANNUZZI, supra note 86 , at 61 . 
ror . . ."137 Lysias does nothing to offer intrigue to his listeners; rather, lie appeals only to their most utilitarian side. This appeal may liave been aimed at the audience's predilections, but in the end, it is ineffective. While Pliaedrus is certainly utilitarian, he is also a human being. And human beings are moved by stories. ${ }^{138}$ To be sure, Phaedrus is impressed with the speech's rhetoric (if not enlightened by its substance). ${ }^{139}$ But he nonetheless seeks out Socrates, cliallenging the philosoplier to best Lysias. ${ }^{140}$ Clearly, Phaedrus is looking for nore.

\section{B. The Defense's Cross-Examination: Passion as Power}

Upon hearing Phaedrus recite Lysias' speech, Socrates is certainly not impressed. ${ }^{141}$ But in order to persuade Phaedrus, Socrates must first gauge his companion's reaction to the speech. In this respect, Socrates is given an opportunity to interact with Pliaedrus that, at least within the confines of the dialogue, Lysias is not. ${ }^{142}$ Socrates' examination of Pliaedrus is complex and occurs simultaneously on two levels: that of cross-examination and of voir dire. Inasmucl as Phaedrus was the bearer of Lysias' argu-

137. DOBSON, supra note 42 , at 88 .

138. This truism holds as much in a courtroom as it does by a riverbank. See RICHARD A. LUCAS \& K. BRYAN MCCOY, THE WINNING EDGE § 8.2 (1993) (recommending that trial lawyers read fairy tales such as Brothers Grimm's Hansel and Gretel and Hans Christian Andersen's The Emperor's New Clothes to learn dramatic effect in planning the opening statement); see also WRIGHT, supra note 38 , at 174 . Wright advises lawyers: "Structure with drama in mind. Structuring your story will make it sound more reasonable, but structuring it for dramatic reasons is equally important. Create interest! Build toward the important part of the story." Id. He also warns, "Jurors use common sense and are not impressed by technical arguments." Id. at 176.

139. See PHAEDRUS, supra note 1 , at 234c-e (Phaedrus praising Lysias' speech for its ability to say more things about the same matter than anyone else, and in an eloquent way.)

140. See id. at $236 \mathrm{c}-37 \mathrm{a}$.

141. See id. at 234d-235a. Socrates criticizes Lysias by asking Phaedrus:

Should you and I also praise the speech on the grounds that its creator has said what he should, and not just because he has said things clearly and in a well-rounded fashion, and each and all of his words are precisely turned? . . . I did not think even Lysias himself thought the speech good enough; and in fact he seemed to me, Phaedrus, ... to have said the same things two or three times over, as if he wasn't altogether well off so far as concerns saying many things about the same subject....

Id.

142. Lysias' ability to manipulate his own speech according to the reaction of the audience is further hanpered by the fact that his speech was written and, as such, is relatively inflexible. See supra text accompanying note 124 . 
ment and testified as to its content, ${ }^{143}$ Socrates is cross-examining Phaedrus. Socrates' questions are an attempt to determine the depth of Phaedrus' behef in what he has heard. He doesn't attack Phaedrus' esteem for Lysias' speech, at least not directly. This indirect approach is another example of Socrates' attempt to detach Phaedrus from Lysias' argument. ${ }^{144}$ Furthermore, by not letting Phaedrus recite the speech from meinory, he prevents Phaedrus from becoming accountable for Lysias' words. Lysias' speech must defend itself. ${ }^{145}$ With Phaedrus substantively a juror in the case, Socrates would be ill-advised to alienate the very person he wishes to persuade. ${ }^{146}$

Socrates' examination of Phaedrus' reaction reveals that Phaedrus is impressed by the weightiness and verbosity of Lysias' argument. Indeed, when pushed by Socrates, Phaedrus tells him that he most enjoyed the speech because "[n]othing waiting in the subject to be expressed in a way worthy of it has been left out, so that no one could ever say things in greater quantity or of greater value than he has said."147 Armed with this knowledge, Socrates knows just where to attack.

Although the timing is different from the voir dire of a modern trial, Socrates' initial questioning of Phaedrus may be read also as his voir dire of Phaedrus as a juror, as the lawyer's exploration of the juror's pre-existing behief system. Socrates does not have the option to peremptorily strike Phaedrus from the trial, ${ }^{148}$ but he can tailor his argument to Phaedrus' interests. ${ }^{149}$ Put in this hight, Socrates is given a distinct advantage over Lysias. Al-

143. Initially, Phaedrus wanted to inipress Socrates with his memorization of the speech. However, Socrates soon forced him to admit that he had the speech itself on his person. "[F]ond as I am of you, if Lysias is also here, I am not really inclimed to offer myself to you to practi[c]e on." PHAEDRUS, supra note 1, at 228e.

144. For a discussion of the elements of detachment in the dialogue, see supra note 34.

145. See PHAEDRUS, supra note 1 , at $228 \mathrm{~d}-\mathrm{e}$.

146. Thus, Socrates effusively conpliments Phaedrus on his reading of Lysias' speech. See id. at 234 d.

147. Id. at $235 \mathrm{~b}$.

148. Cf. FED. R. CRIM. P. 24(b) (describing peremptory challenges).

149. Socrates, questioning Phaedrus, is also similar to a litigator watching the reactions of the jury as her opponent puts on his case. See LuCAS \& MCCOY, supra note 138, \$ 1.4 (instructing a trial advocate how to interpret a juror's reaction to information). Such observations are crucial and often define the way a litigator will present her own case. Another analogy would be to the appellate hitigator who directs her argument according to the questions asked by the judges hearing the case. 
though this advantage may seem unfair, it was Lysias who voluntarily chose his weak position by offering his argument in writing. ${ }^{150}$

The multilevel approach of Socrates' questioning causes difficulties. In the context of his cross-examination of Phaedrus as witness, rather than his voir dire of Phaedrus as juror, Socrates works to inject doubts imto Phaedrus' testimony. ${ }^{151}$ In a norinal cross-examination, a crucial strategy would be to impeach the witness by attacking his credibility and menory. ${ }^{152}$ In this way, the advocate can gain control of the witness and use his testimony against him. But Socrates cannot implement this tactic with Phaedrus, because Phaedrus is a juror as well as a witness. If Socrates is to win Phaedrus over, he must not directly impeach him. What we see instead is a gentle "correction" of Phaedrus' understanding. This is the approach a lawyer should take whenever he observes that the jury might be sympathetic, for whatever reason, to the witness or opponent. ${ }^{153}$ A direct attack may only serve to alienate the jury.

Socrates, rather than directly attacking Phaedrus' praise of Lysias, hides his argument behind the authority of "men and women of antiquity and wisdom who have spoken and written about the subject."154 Indeed, Socrates covers his head as he gives this speech, refusing to allow Phaedrus (or even the reader) to associate the words that he speaks with his identity or that of the lover. ${ }^{155}$ In hiterally concealing his criticisms, Socrates is carefully preparing his refutation of Lysias' argument. By detaching himself from the argument he is about to offer, Socrates avoids antagonizing Phaedrus and ensures that Phaedrus learns of the flaws im

150. But recall that Lysias will be given a chance to respond when Phaedrus reports his conversation with Socrates back to him, as Socrates commands Phaedrus to do. See PHAEDRUS, supra note 1 , at $278 \mathrm{~b}-\mathrm{c}$.

151. It is precisely because of the complexities that arise when jurors become involved in the trial itself that jurors are disallowed from being witnesses. See FED. R. EVID. 606(a).

152. See LANNUZZI, supra note 86 , at 216 . Iannuzzi recommends three tactics for upending a witness under cross and curtailing the adverse testimony: 1) attack the general capacity of the witness; 2) attack the witness' recollection of specific knowledge pertaining to the event; 3) attack and impeach the personal character and integrity of the witness. See id.

153. Interview with Charles Becton, Professor of Trial Advocacy, in Durham, N.C. (Feb. 9, 1997).

154. PHAEDRUS, supra note 1 , at $235 \mathrm{~b}$.

155. See id. at 237a. 
Lysias' argument, but not, it seems, from Socrates. Then, after Phaedrus has been disillusioned about Lysias, Socrates can step in and build up his own argument in favor of the lover.

Moreover, Socrates coyly refuses to offer his argument, even concealed, until Phaedrus virtually forces him to speak. ${ }^{156}$ Socrates flatters Phaedrus by making Phaedrus feel as though he were a part of the process, spurring the conversation. This tactical move is also praised by trial strategists. ${ }^{157}$ While voir dire is the only actual conversation between a lawyer and jury, there are other ways to encourage a juror to participate in the conversation going on in the courtroom. ${ }^{158}$ The opening and closing remarks are conversations, albeit one-sided. The eye roll, raised voice, conspiratorial whisper and rhetorical question are also but a few of the ways in which a lawyer can invite the participation of a juror. A litigator should strive to make the juror feel involved in the trial-and in its outcome. ${ }^{159}$ Socrates' ploy of pulling Phaedrus into the process instills in Phaedrus some sense of vested interest, a sense of authorship in what Socrates will say. It does not matter tliat what Socrates is about to say Socrates himself will soon refute. The point is to engage the juror or the witness in the process, to persuade the juror that the earlier evidence has misled him. In short, a successful litigator will guide the juror or witness to his own set of beliefs. ${ }^{160}$

156. See id. at 236d ("We're alone in a deserted place, and 1 am stronger and younger than you; froin all of which 'grasp the ineaning of my words,' and don't be inclined to prefer to be forced to speak than to do it voluntarily.").

157. See, e.g., WRIGHr, supra note 38, at 27 (stating that jurors who are encouraged to actively participate in voir dire will also listen more closely during trial and will participate in jury debiberations).

158. See THEODORE I. KOSKOFF, EsSAYS ON TRIAL ADVOCACY 16 (1988) (noting the importance of tone, body language and word choice in stimulating juror interest in a lawyer's comments); LUCAS \& MCCOY, supra note 138, §§ 5.1-5.4 (describing how embedded questions, comments, and commands influence and persuade jurors).

159. See KosKoF, supra note 158 , at 28.

160. This tactic is a common strategy for Socrates. Called the moment of aporia [difficulty or perplexity], see LIDDELL \& SCOTT, supra note 6, at 105, it occurs when Socrates has successfully entangled his interlocutor in such a web of confusion that the imterlocutor no longer believes that which he once held to be certain. See DREW A. HYLAND, THE ORIGINS OF PHILOSOPHY: ITS RISE IN MYTH AND THE PRE-SOCRATICS 348-49 (1990) (exploring both Socrates' claim of aporia in the Apology and its stance as a mode of philosophy, that is, a state of wonderment as to how things are, which spurs a quest for self-knowledge). Once that state of confusion has been reached, Socrates can easily guide the interlocutor to accept Socrates' interpretation of the subject matter. 
Despite the differences between a traditional cross-examination and Socrates' "cross" of Phaedrus' recitation of Lysias' speech, there is an important lesson here for a trial lawyer. It is important to appear as a friend to the jury and to treat witnesses fairly. Badgering a witness or humiliating the other party can often alienate the jury. ${ }^{161}$ Thus, despite the adversarial process of a trial, an effective advocate can benefit by non-adversarial means. This is not to suggest that a lawyer should never be aggressive or forceful against a witness or the opposition. Rather, there simply are times when less forceful, more gentle means are far more persuasive.

In this first speech in response to Lysias, Socrates begins to address the greatest weakness of his chient: the lover's lack of control. This tactic mirrors the defensive direct examination that is recommended by trial strategists. ${ }^{162}$ This step is absolutely crucial to Socrates' persuasion of Phaedrus. Given the empirical evidence that Lysias has stacked up against the lover-his inability to hide his affection, to maintain composure around his beloved, to act according to reason and not irrational desire-Socrates must confront the weakness immediately. Any subsequent argument in favor of the lover will fail if Socrates cannot account for the lover's lack of control.

While virtually every book on trial strategy recommends confronting a chent's weaknesses directly, ${ }^{163}$ none would likely go so far as to suggest the method Socrates einploys here. ${ }^{164} \mathrm{He}$ is actually arguing against his own client. ${ }^{165}$ To be sure, he does it

161. See Model Rules OF Professional Conduct Rule 4.4 (1992) (prohibiting a lawyer froin embarrassing or burdening a third person in the advocacy of his client); WRIGHT, supra note 38 , at $240-41$ (advocating that a trial lawyer impress the jury by being fair to the witness in cross-examination).

162. See, e.g., LUBET, supra note 132, at 24, 31-32.

163. See, e.g., id. at 31 (contending that $[\mathrm{b}] \mathrm{bd}$ information will have less sting if the witness offers it lierself, and conversely that it will be all the more damning if the witness is seen as having tried to hide the bad facts"); WRIGHT, supra note 38 at 11 (using example of lawyer Joe Jamail, who began one voir dire by telling the jurors, "Folks, I have a problein. This fellow I represent is a drunk.").

164. Indeed, such rogue techniques may violate a lawyer's duty to provide zealous advocacy for his clients. See MODEL RULES OF PROFESSIONAL CONDUCT, supra note 161, at Rule 1.1, Preamble.

165. See, e.g., PHAEdRus, supra note 1 , at 235 e (Socrates begins his argument against the lover by stating "[w] $w$. . . , if he is saying that one should grant favors to the nonlover rather than the lover, can omit to praise the good sense of the one and censure the lack of sense of the other"). 
with his head covered and will soon refute his own argument; but he is clearly taking a great risk. Socrates makes this argument, which even Phaedrus agrees is fluent in language and divinely inspired, ${ }^{166}$ in order to defeat any counterargument that might later follow his actual defense of love. But by setting forth the best argument for the non-lover (and against the lover) he runs the risk that his own later argument will not be able to compete or, at the very least, that the juror will be confused by Socrates' conflicting arguments. Socrates' gamesmanship succeeds here largely because of his supreme confidence in the strength of his subsequent defense of Love. The lesson for today's litigators is to have the courage of conviction to take the risks necessary to advance a client's interests.

Socrates' speech, while taking the same substantive position as Lysias', narks a subtle change in tempo and perspective. Lysias' node of speaking is very technical, addressing the perspectives of the lover and non-lover dryly and formally. Socrates, on the other hand, is so passionate that he fears his speech will lapse into verse. ${ }^{167} \mathrm{He}$ begins with the definition of Love and goes on to tell the tragic story of the lover, enslaved by his own passion for his beloved. ${ }^{168}$ Before he gets to the actual praise of the nonlover, Socrates stops, saying "There, Phaedrus, it's as I said it would be. You'll hear nothing more than that from me . ..."169 When Phaedrus complains that he thought the speech was just in its middle and that Socrates would go on to praise the non-lover, Socrates stops him, admitting he has lost control and will not continue. ${ }^{170}$ Thus, Socrates never actually speaks about the nonlover, only the lover. Even while he is imitating Lysias' encomium on the non-lover, he is introducing the jury to his client, the lover. And he is doing so quite dramatically, in "epic verses." giving examples of the emotional torture suffered by a lover, ${ }^{172}$ he is addressing an issue of which every juror, and every human,

166. See PHAEDRUS, supra note 1 , at $238 \mathrm{c}-\mathrm{d}$.

167. See id. at 241 .

168. See id. at $237 \mathrm{~b}-41 \mathrm{e}$.

169. Id. at $241 \mathrm{~d}$.

170. See id. at $241 \mathrm{e}$.

171. See id.

172. Socrates tells Phaedrus, for instance, that the lover, ruled by a desire he cannot control, is spumed in society, deceitful, manipulative, and selfish. See id. at 238e-241d. 
is aware. The lover is no longer a lawless, dangerous unknown in society but a ravaged-and recognizable-soul.

Because the issue at bar is whether the lover can be beneficial for the beloved, any way in which a lover can demonstrate control and rationality will be viewed positively. Socrates does just this in his first speech. First, he indicates that he was on the verge of losing control. ${ }^{173}$ But then he catches himself, saying he will continue no more with this speech. ${ }^{174}$ Such a show of control, especially by one who will soon purport to be a lover, goes a long way toward deflecting claims of reckless behavior. Socrates thus demonstrates that a lover can both be swept away by divine madness and be able to control such madness so as to benefit both the lover and the beloved.

Importantly, Socrates does not merely reiterate the rhetorical style of Lysias' speech. Where Lysias simply compares the nonlover to the lover and finds the latter wanting, Socrates begins his first speech with a definition of Love. Of Love he says:

[T] he irrational desire which has gained control over judgement which urges a man towards the right, borne towards pleasure in beauty, and which is forcefully reinforced by the desires related to it in its pursuit of bodily beauty, overcoming them in its course, and takes its naine from its very force ["rhôme"]-this is called love ["erōs"]. ${ }^{175}$

Even though Socrates later recants this earlier speech criticizing the lover, he retains this rudimentary definition and expands upon it. ${ }^{176}$ Socrates is here letting Phaedrus know immediately the theme of his argument for the lover: it is absolutely essential to know what Love is in order to understand the divine nature of the lover. Socrates' opening remarks are thus like those of a skilled advocate who introduces his theme in his very first sentence and carries that theine throughout the entire case. ${ }^{177}$ Socrates never loses sight of this theme; indeed, he criticizes Lysias for not having

173. As he cries out to Phaedrus: "Haven't you noticed, my dear fellow, that I'm already uttering epic verses ... . ? What do you think I'll produce if I begin praising the [non-lover]?" PHAEDRUS, supra note 1, at 241 e.

174. See id.

175. See id. at $238 \mathrm{~b}-\mathrm{c}$.

176. See id. at $263 \mathrm{~d}-264 \mathrm{c}$.

177. Introducing one's theme early in the case, even as early as voir dire, is highly recommended. See IANNUZZI, supra note 86, at 111-16; LUBET, supra note 132, at 7-9; WRIGHT, supra note 38 , at 10-12. 
done likewise. ${ }^{178}$ With his defining theme in place, Socrates is prepared to begin his direct persuasion of Phaedrus in earnest.

\section{THE DEFENSE}

\section{A. The Lover Takes the Stand}

Following Socrates' atteinpt to best Lysias' speech in favor of the non-lover, the philosopher gives another speech. This time he praises the lover. Socrates tells Phaedrus that he is compelled to give this speech because his "daimon"179 has directed him, telling him that he has done wrong in his first speech. He has "committed an offence against what belongs to the gods," an act which he and Phaedrus agree is most reprehensible. ${ }^{180}$ Socrates continues by comparing his own situation to that of Stesichorus, a poet who falsely libeled Helen of Troy. To appease the gods, Stesichorus composed a "palinode," 181 which confessed his misdeed and corrected his story. ${ }^{182}$ Now, Socrates inust correct, as it were, his own story falsely told. Thus, in imitation of Stesichorus' palinode, Socrates offers his own defense of love.

Socrates' palinode is both long and complex. It is composed of a myth in which he describes the soul and its relationship to the truth. There are four areas of Socrates' myth that illuminate Socrates' persuasion of Phaedrus: the nature of the soul, ${ }^{183}$ the divine banquet in which mortal and divine souls feast upon a vision of truth, ${ }^{184}$ the relationship between the lover and the beloved as it pertains to the recollection of this vision, ${ }^{185}$ and the

178. See PHAEDRUS, supra note 1 , at 263d-264a. Socrates faults Lysias for not beginning his speech with a definition of the subject matter: "Indeed he seems to be a long way from doing what we're looking for, since he doesn't even begin at the beginning, but from the end, trying to swim through his speech in reverse, on his back . . .." Id. at $264 \mathrm{a}$.

179. "Daimon" literally means inferior divine being or demon. See LIDDELL \& SCOTT, supra note 6 , at 171 . Socrates explains his relationship with his daimon in the Apology. For Socrates, the daimon acts like a conscience. While it does not tell him how lie should behave and what he should say, it does tell him when he has acted or spoken wrongly. See APOLOGY, supra note 21, at 31c-d; see also supra note 57 (describing Socrates' use of the term in the Symposium).

180. See APOLOGY, supra note 5, at 242c, $242 \mathrm{~d}$.

181. Specifically, a recantation, named after "an ode by Stesichorus, in which lie recants his attack upon Helen." LIDDELL \& SCOTT, supra note 6, at 588.

182. See PHAEDRUS, supra note 1 , at $243 a-b$.

183. See infra notes $198-226$ and accompanying text.

184. See infra text accompanying notes 207-08.

185. See infra text accompanying notes 221-26. As will be described infra, Socrates 
benefits a beloved might receive as a result of this relationship with the lover. ${ }^{186}$ Through his palinode, Socrates transforms the weaknesses of the lover into strengths that any beloved would admire, and his rhetorical method of doing so ensures that Phaedrus in particular will be entranced.

While Socrates holds Phaedrus responsible for the first speech offered, ${ }^{187}$ this speech he dedicates to Stesichorus. ${ }^{188}$ Why has Socrates distanced Phaedrus from this myth? The story he is about to tell is very emotionally powerful, that is, very erotic. Socrates is afraid of scaring Phaedrus. ${ }^{189}$ So might a lawyer attempt to distance a juror from inaterial that is too emotional, too violent. By distancing Phaedrus, Socrates protects him until Socrates has convinced him that the passion of the lover is a virtue, not a dangerous vice. ${ }^{190}$ This distance is especially important given that Socrates clearly suggests that the beloved is the cause of the lover's irrational loss of control. ${ }^{191}$ Socrates has not yet convinced Phaedrus that the lover's loss of control is a positive event. Until he is able to do this, Socrates does not want Phaedrus to feel guilt or danger as a result of his own status as beloved. So Socrates distances his story from both himself and Phaedrus. ${ }^{192}$ But, even if Phaedrus is released from immediate fear that Socrates will harm

uses the palinode to describe man's journey to Truth as one of recollection.

186. See id.

187. Socrates refuses to speak until Phaedrus forces him to do so. See supra note 156 and accompanying text.

188. See PHAEDRUS, supra note 1 , at 244 .

189. In a similar sense, Plato protects the reader from the very erotic and potentially dangerous insinuations of the Symposium by framing it within a series of storytellers. We are told at the very beginning of the Symposium that the story we are to hear took place some time ago, and was told to the current teller by someone else who heard it from someone else who heard it froin yet another person who actually witnessed the event. See SYMPOSIUM, supra note 4, at 172a-b; see also ROSEN, supra note 82, at 2 (noting that "[t]he Symposium may be tentatively described as a series of recollections within a recollection").

190. See also supra note 34 . Like the concealing shade of the tree, Socrates' action protects Phaedrus from the emotive power of Love until Phaedrus is ready.

191. See PHAEdRUS, supra note 1 , at 251a-52b.

192. Compare Socrates' strategy here with the apparent-loss of control in his earlier speech. See supra notes 167-72 and accompanying text. That loss of control, rather than scaring Phaedrus, merely excited the younger man. He wanted Socrates to continue, to break into epic verse even, so strong was his desire to hear a speech about love. Socrates' control at that point, coupled with his detachment at this early stage of a very erotic story, should both satisfy Phaedrus' desire to hear the speech and enable Socrates to persuade him of the benefits of the lover. 
him, he can still regard himself as the initial instigator of the conversation. This detached and formalistic mode of participation still ensures a sense of involvement and commitment to the speech. ${ }^{193}$

Like a good trial lawyer, Socrates begins the defense of his client by immediately confronting the lover's greatest weakness: ${ }^{194}$ his passion. The fact that the lover acts irrationally was the strongest element of Lysias' attack. ${ }^{195}$ Here, Socrates counters by turning the lover's madness imto a strength. The lover's madness, he says, is a divine gift. "[S]uch madness is given by the gods to allow [the lover and the beloved] to achieve the greatest good fortune ...."196 The lover's passion is not a sickness to be avoided, but rather a divine gift whiclı allows mankind to accomplish great achievements. ${ }^{197}$

Socrates then offers Phaedrus a myth about the nature of the soul, both immortal and mortal. He calls this myth an apodeixus" ${ }^{198}$ compreliended by "observing experiences and actions belonging to [the soul]."199 Unlike his opponent, Socrates is setting up the mode of his argument as a storytelling. Trial strategists strongly recommend using narrative, especially storytelling, to persuade the jury. ${ }^{200}$ Socrates' inessage is complex, and the concepts he is discussing are not immediately observable; by using a narrative format, he grounds the abstract points of his argument in everyday experience, making the argument more easily understood and remembered. ${ }^{201}$

At this point, Socrates' opportunity to question Phaedrus throughout the opening passages of the dialogue pays off. Socrates knows already that Phaedrus is easily affected by the medium of

193. See also supra note 154-56 and accompanying text.

194. See WRIGHT, supra note 38 , at 180.

195. See supra note 32.

196. PHAEDRUS, supra note 1 , at $245 \mathrm{c}$. As such, the madness granted to the lover is one of the four divine gifts of madness, together with prophetic madness, madness which acts as an interpreter between gods and man, and the madness which creates poetry. See id. at $244 \mathrm{a}-45 \mathrm{a}$.

197. See id. at $245 b$.

198. A "showing forth." The word also connotes "proofs, arguments in proof of" or an "exposition." LmDELL \& SCOTT, supra note 6, at 96.

199. PHAEDRUS, supra note 1 , at 24506-7.

200. See supra note 138 and accompanying text.

201. See WRIGHT, supra note 38 , at 178-80 (explaining how litigators can mamtain interest with storytelling techniques); see also KosKOFF, supra note 158, at 27 (describing the use of "impact phrases," powerful story-like phrases that drive home to the juror the intent of the argument). 
the myth. ${ }^{202}$ Indeed, myths were often used in ancient Greece because of their capacity to tell a story with moral import to a wide audience. ${ }^{203}$ Moreover, Socrates knows that Phaedrus is interested more in rhetorical style than in substance. So, it is with style-mythic style-that Socrates now intends to woo his imterlocutor. ${ }^{204}$ By telling a myth, Socrates can identify directly with Phaedrus and, as such, more easily persuade him. This technique has been termed "estabhshing rapport" by one group of trial advocates. ${ }^{205}$ "Rapport is not achieved through eloquence, logic, or flattery. Rapport is achieved by matching or mirroring another person's body language, system of communication, and method of processing information. ... It is a dynamic, ongoing way of getting the other person to behieve you and to beheve in you."206 Socrates offers this myth primarily to establish a rapport with Phaedrus; he wants to tell Phaedrus that Phaedrus and Socrates are of the same soul, the soul of the most wise, the philosopher. Socrates then wants to persuade Phaedrus that, given the identical (and superior) nature of their souls, a relationship between Socrates and Phaedrus would enable both to transcend into a world of ultimate knowledge and beauty. With this purpose, Socrates launches his palinode.

Socrates portrays the soul as an immortal entity, complex and conflicted. The soul is winged and comprised of three different parts, which Socrates describes as a white horse, a dark horse, and

202. See, e.g., PHAEDRUS, supra note 1, at 229c. At the beginning of the dialogue, when discussing the myth of the rape of young Oreithuia, Phaedrus displays his interest in myths by questioning the truthfulness of their origins.

203. See BoWrA, supra note 41 , at 115-20. Today, popular culture, especially television, is viewed as providing society with the bonds of shared experience. See Edward Rubin, Television and the Experience of Citizenship, 68 TEX. L. REV. 1155, 1165 (1990), reprinted in RONALD K.I. COLLINS \& DAVID M. SKOVER, THE DEATH OF DISCOURSE 60 (1996) ("[T]elevision creates an electronic network that connects several hundred million people across a continent to a single source of entertainment and information. It provides us with a common set of direct experiences, a shared body of images, situations, and events."). This analogy suggests that a trial lawyer can rely on references to "The Cosby Show" or "Melrose Place" for communal points of reference, much as Socrates relies on the myths of ancient Greece. See also LUBET, supra note 132, at 397 (observing that "references are just as likely to be taken froni motion pictures, television, popular songs, fairy tales, or, alas, advertiseinents").

204. See id at 229b-c. Cf. GRISWOLD, supra note 5, at 141 ("As is true for the Platonic dialogues in general, the partially buried meaning of Plato's myths is accessible only to the reader willing to engage in a dialogue with them.").

205. See LUCAS \& MCCOY, supra note 138, \$§ 2.1-2.3.

206. Id, at 22-23. 
a charioteer. Here, the human soul differs from the divine soul, for the divine soul has two white horses, but the human soul is driven by a white and a dark horse. ${ }^{207}$ The charioteer is man's reason and his goal is to guide the horses on the soul's journey beyond the heavens to feast upon Truth. The dark horse, however, is wanton and passionate and is forever chomping at the bit, trying to pull the soul toward base pleasures. ${ }^{203}$

The journey of the souls is far from easy. Because of the conflicting natures of the horses and charioteers, combined with the violent rush as every soul struggles upward at once, there is great frenzy and trampling. ${ }^{209}$ Of the human souls, only very few break through the heavens to see Truth in all its forms, ${ }^{210}$ and those only see it partially and inomentarily. ${ }^{211}$ The others, broken and trampled, do not feast upon Truth, but "feed upon what only appears to nourish them."212

Several issues here deserve our attention. Interestingly, Socrates has divided souls into twelve different types; each type follows its Olympian god in its journey beyond the heavens. ${ }^{213}$ Moreover, each soul is further categorized according to the degree to which it envisions Truth in its journey around the heavens. ${ }^{214} \mathrm{~A}$ soul with the best vision of Truth becomes in human form a "lover of wisdom or of beauty, or devoted to the Muses and to love."215 Socrates is here not ouly establishing rapport between himself and Phaedrus, he is compelling Phaedrus to identify himself with Socrates. Socrates has in effect just told Phaedrus that, of all the different types of souls that a human being might have, theirs is supreme. As Socrates suggests to Phaedrus, they are both followers of Zeus, ${ }^{216}$ and followers of Zeus are philosophers. ${ }^{217}$ Socrates is a philosopher. It follows that, since he and Phaedrus are en-

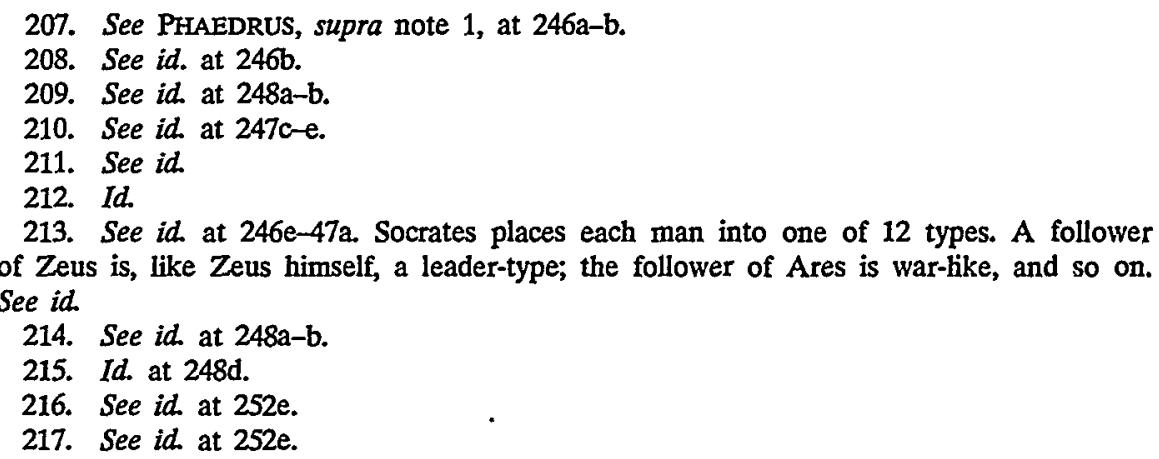


gaged in this examination of Eros, that Phaedrus too, is a philosopher and a most superior being. Phaedrus, like any human being, will need very hittle persuasion before considering himself to belong to that highest quadrant of human souls. ${ }^{218}$ Here, Socrates is flattering Phaedrus, plain and simple. He wants Phaedrus to see himself as a philosopher like Socrates, because if Phaedrus has that self-image, he will becoine Socrates' ally in the city. ${ }^{219}$

It is standard practice in a criminal trial for a prosecutor to try to demonize the defendant, to make him seem "not like us." When the prosecutor succeeds, the defendant's apparent "otherness" allows the jury to condemn him without compunction. ${ }^{220}$ The defense attorney, on the other hand, tries to portray the defendant as "one of us." Lysias atteinpts to demonize the lover; Socrates attempts to humanize him.

Moreover, as Socrates continues his myth, this relationship is firmly cemented to a recollection of that earlier, imperfectly envisioned, Truth. In a very complex exposition, Socrates describes low a lover, upon seeing the beauty of a beloved, is struck by a recollection of his earlier vision of Truth. ${ }^{221}$ This recollection sparks the regrowth of the wings of his soul, which liad shriveled through malnourishment. ${ }^{222}$ The soul of the beloved, seeing the

218. However on another level, Plato, the author of the dialogue, is trying to communicate with all types of people, or at least with every person who will read his dialogue. Why, then does he so clearly differentiate the different types? As Lysias' opening statement exemplifies, the author of a dialogue cannot directly address every reader of his written document. He must employ other techniques to gain the reader's trust. See supra notes 115-16 and accompanying text. Plato is trying to encompass every type of soul, every type of personality, every type of character, so that everyone who reads this dialogue will identify with it and with its argument. This poses a problem for Plato when Socrates actually places these different character types within a hierarchy. See infra note 238 and accompanying text. Plato addresses this problem by relying on the formal style of dialogue. In doing so, he makes philosophers of his audience by encouraging them to respond to, and participate in, the dialogue. See infra notes 227-30 and accompanying text.

219. See GRISwOLD, supra note 5, at 26 (noting that Socrates calls Phaedrus "friend" or some derivative no less than 18 times in the dialogue). It is essential to realize that Socrates is not looking for a simple, unconditional friendship. The purpose of his friendship is political: Socrates needs a connection inside the political and social circles of the city and Phaedrus can provide it. See id. at 26-27.

220. See VINSON, supra note 74 , at 92 (suggesting that plaintiff lawyers try to get jurors to attribute any undesirable behavior to the personal characteristics of the defendant so that they will view the defendant as "fundainentally evil").

221. See PHAEDRUS, supra note 1 , at $253 \mathrm{~d}-54 \mathrm{c}$.

222. See id. at $255 \mathrm{c}-\mathrm{d}$. 
light of love shining from the lover, recalls its own vision of Truth and is also sparked into regrowth. ${ }^{223}$ The charioteer of the lover's soul, his reason, urged on by this new recollection, attempts to lead the soul to further recollections of Truth by rational endeavors with the beloved. ${ }^{224}$ The dark horse of passion has different ideas, of course, and its vision of the beloved spurs the lover to couple licentiously with the beloved. ${ }^{225}$ Such coupling, however, would ruin the intellectual pursuit for both the lover and beloved as their lofty vision of the Truth would be forever befuddled by their attraction for each other. Thus, while attracted to the beauty each sees in the other, the lover and the beloved must struggle not to fall prey to their sexual desires, but must imstead use this attraction to further their regrowth and recollection of Truth. ${ }^{226}$

In arguing for the lover, Socrates has actually envisioned a new type of lover. He has created, to quote a cliche, the "Platonic lover." He has taken the sexual energy that earlier darkened the nature of the intemperate lover and has redirected it towards a more intellectual purpose. Importantly, the sexual energy between lover and beloved is not destroyed by this redirection; such tension must necessarily continue to provide the impetus for imtellectual growth. With this new characterization, Socrates completes the transformation of the lover from an irrational and dangerous menace to a beneficial, purposeful being.

Recall Socrates' earlier attempt to distance Phaedrus from the myth he was about to tell. ${ }^{227}$ Given this recounting of the heady relationship between lover and beloved, Socrates' conservative move now seems wise. Simultaneously, however, Socrates also allowed Phaedrus to continue to see himself as beloved, a beautiful, desirable being. Phaedrus has placed himself in the middle of a duel between Lysias and Socrates because of his desire to be portrayed as such. Now, he can begin to enjoy this relationship, for Socrates is now satisfying all his wishes: flattery, physical attraction, and intellectual stimulation. All this is offered as a result of the divine gift of madness, coupled with philosophic control.

223. See id. at $255 \mathrm{~d}-\mathrm{e}$.

224. See id. at 256a-b.

225. See id. at $254 \mathrm{a}-\mathrm{b}$.

226. See id. at $249 \mathrm{~d}-50 \mathrm{c}$.

227. See supra note 34 and accompanying text. 
Most importantly, whereas Lysias' argument portrayed the lover as a weak individual, dangerous and inad with desire. Socrates has turned this argument on its head. Now the lover, though maddened with desire, is actually the most beneficial person for whom a beloved could hope. The lover, spurred on by his recollection of Truth, can lead the beloved to Truth. The non-lover is, on the other hand, motivated not by Truth but by its semblance and thus can lead the beloved only to illusion. Socrates has thus not only turned his client's weakness into a strength, but he has portrayed his chent as essential to the well-being of the person he is trying to persuade.

\section{B. Rhetoric as Substance}

What of anyone else who might hear this argument? That is, could Socrates, with the same words, be as persuasive? Socrates has created this myth for Phaedrus and for the persuasion of Phaedrus. The persuasion of others, directed by different motives, would require different incentives, different techniques. This immediately points to a question: would Socrates recommend this method of persuasion to a larger audience, say, to an entire jury? With this question we return full circle to Socrates' statement that the method of persuasion in the law courts, in the public forum, is the same method used in the private persuasion of a single individual.

Ultimately, the question of whether the public persuasion of an entire jury comprised of several different personalities is as effective as the private persuasion of one individual with one known personality revolves around the issue of control. As Socrates' persuasion of Phaedrus suggests, persuasion depends on control, and in order to control the audience, it is essential to know the audience. It is for this reason that Socrates criticizes the written word. ${ }^{228}$ As he suggests, the spoken word is superior because the speaker knows precisely whom he is addressing and can frame his argument to that specific individual.

The lawyer attempting to convince a jury must know his audience equally well. Acquiring this knowledge is arduous indeed. But while it is certainly difficult to know all the significant personal

228. See PHAEDRUS, supra note 1 , at 275 d-e (comparing the written document to a painting whose meaning is left up to the interpreter to decide); see also supra Part V (discussing Socrates' criticism of the written word). 
quirks and beliefs of every jury member, this difficulty is ameliorated in a modern trial by voir dire. Lawyers have a chance not only to discover the various personalities within the panel but, to a limited extent, to define that panel according to their needs. Thus a lawyer might pick a panel of jurors that can not only identify with his client, but can identify with each other. This identification will ease the lawyer's task somewhat.

However, no group of twelve will have completely identical belief systems. A lawyer, then, has two options. He can speak in generalizations broad enough that most, if not all, jurors will find soine spark of recognition. Socrates' general use of myths is imdicative of such an effort. ${ }^{229}$ Socrates uses several myths throughout the dialogue. Myths were an accepted method of communication in ancient Greece, ${ }^{230}$ people were comfortable with their form as a mechanism for telling stories with inoral or normative implications. Moreover, the use of several inyths increases the chance that at least one will inspire recognition in the listener.

A lawyer can also identify with a juror by telling a story with which the juror will want to identify himself. Socrates' myth of the soul, for instance, gives an individual several factors with which to identify: the conflicted nature of his emotions, the different types of personality, or his current profession and interests. There is enough flexibility and ambiguity in the description that any individual might feel Socrates las selected him, and him alone, to be

229. An important benefit of arguing through myth is that such an argument is very difficult to attack. Note that a trial lawyer uses a somewhat analogous method: he tells his chent's story, not his own. As Socrates mentioned earher, myths are not important to him for their authenticity or factual foundations; rather they are important to him as tools for leaming about himself. See PHAEDRUS, supra note 1 , at $229 \mathrm{c}-30 \mathrm{a}$. Were Phaedrus or someone else to question Socrates on the factual accuracy of his myth, Socrates would escape criticism by relying on his use of metaphor; he was telling a story, not offering a factual account. The only effective rebuttal would be another myth that offers an altemative explanation for why humans act as they do.

This controversy between two myths would be analogous to the two "myths" told to a jury, one by the prosecutor and another by the defense attomey. Both advocates create a story, a mythical explanation, incorporating all the evident facts into a plausible scenario. Each story emphasizes the strengths of facts that are favorable to its side and downplays facts that weaken it. In the end, it is up to the jury to decide which story was more plausible, which story they "liked better." In the Phaedrus, the stories that are told both describe the nature of the lover. It is up to Phaedrus, the admirer of rhetoric, to decide which story he likes better. As such, the contest inevitably turns on rhetoric, not upon substance. This is just as Phaedrus would like it to be. And pleasing Phaedrus is just what Socrates wishes to do.

230. See supra text accompanying note 203. 
his companion on the search for Truth. A juror listening to him would want to identify with the different personality types Socrates has described. Moreover, he would want to think that his own version of the truth is closest to the real thing; thus every individual would want to identify himself with the lover. This psychological inducement is aided by the fact that all the human types with lesser degrees of recollection of Truth are less desirable individuals. If you are not a lover, you must be only a king, a farmer, a gymnast, or worst of all, a tyrant. ${ }^{231}$

Socrates does not end his persuasion of Phaedrus with the inyth of the nature of the soul. While that myth certainly describes the utility of companionship with the lover-philosopher, the discussion that follows gives empirical evidence that appeals to Phaedrus' own interest in rhetoric. The discussion allows Socrates to convince Phaedrus of the specific benefits he will receive from the companionship Socrates has described. To convince Phaedrus, Socrates rehes upon his companion's professed interest in rhetoric. Socrates tells Phaedrus that, while an individual can become a good rhetorician by learning the skills and techniques of rhetoric, an imdividual can be an excellent rhetorician only if he has access to the truth of which he is speaking. ${ }^{232}$ Since the lover brings the beloved to Truth, if Phaedrus wishes to become an excellent rhetorician, he must not only learn the "techne"233 of the rhetorician, he must also rely on the lover to carry him to the truth behind his words.

Here we get to the very heart of the skill of persuasion. As Socrates and Phaedrus agree, the person who knows the truth of things will both be able to persuade others to his point of view and also avoid confusing himself. ${ }^{234}$ This does not suggest that this person who knows the truth will necessarily use that truth in the persuasion of his audience. Rather, the key to persuasion is

231. See PHAEDRUS, supra note 1 , at $248 \mathrm{c}-\mathrm{e}$.

232. See id. at $259 \mathrm{e}-60 \mathrm{e}$ (arguing that persuading someone of the truth without knowledge of the truth is as difficult as trying to sell a donkey to a warrior while telling him he is getting a horse (and not knowing the difference between the two)).

233. "Techne" is defined as "skill, craft in work, cunning of hand." LIDDELL \& SCOTT, supra note 6 , at 804 . It can carry a purely industrial meaning, or a connotation of wily cunning. See id.

234. See PHAEDRUS, supra note 1 , at 262 a ("[T]he person who intends to deceive someone else, but be undeceived himself, must have a precise knowledge of the resemblance and the dissimilarity between the things that are."). 
simply knowing the truth. By knowing the truth about a matter, an excellent rhetorician can maneuver more easily around the subtle nuances, the small differences that often make or break an argument. ${ }^{235}$ Thus, whichever argument an individual wishes to proffer, that argument will be more solid, more persuasive, if the individual proffering it knows the truth of the matter. Because the lover is the beloved's conduit to the truth behind all things, a beloved interested in being an excellent rhetorician would be wise to choose as his companion a lover. Socrates' chent is thus no longer dangerous to Phaedrus, but is instead a necessary part of his community. ${ }^{236}$

Socrates' rhetorical maneuver is reflected somewhat in the courtroom. John Iannuzzi writes, "There are two realities: the one of the world outside the courtroom and the other, the world inside the courtroom. . . . The world inside the courtroom does not necessarily comport to reality."237 The key to persuasion is thus not only what reality is, but also knowing what a jury will beheve. As Iannuzzi points out, it is crucial to cast the world described in the courtroom as a version of reality that is not just behevable for the jury, but easily recognizable. It should be a reahity they wish to be true, just as Phaedrus wishes it were true that he could be an excellent rhetorician.

Even though he has completed his palinode, Socrates is not yet finished with his persuasion of Phaedrus. He now offers a demonstration to Phaedrus, showing him precisely that what he has told him is, in fact, the case. Socrates directs Phaedrus in a

235. See id. at $261 \mathrm{a}-62 \mathrm{c}$.

236. Remember, though, that in order to accomplish this persuasion, Socrates has had to sacrifice the lover's sexual relationship with the beloved. See supra text accompanying notes 226-27. The ideal relationship between lover and beloved is intellectual and based on rational conversation. Thus Socrates has directed the passion of the lover away from physical pursuit toward pursuit of rational thought. The very existence of the dark horse and of the conflict between the dark horse and the charioteer might give credence to Lysias' argument. However, Lysias is arguing that the lover cannot control his emotions and that this lack of control is dangerous for the beloved. See supra note 32 and accompanying text. Socrates successfully eludes this argument. Even though the lover does lose control to Eros, see supra notes 195-97 and accompanying text, this is good; this loss of control allows for the growth that will bring both the lover and the beloved to truth. See supra text accompanying notes 221-26. But the successful lover does not lose all control; he holds tight his rein over the licentious dark horse and controls his physical relationship with the beloved. See id. This control of the passions is essential to Socrates' search for Truth.

237. IANNUZZI, supra note 86 , at 43. 
technical discussion of rhetoric. They discuss the different types of rhetoric, the different parts of an argument, and the skills of various rhetoricians. ${ }^{238}$ Socrates also takes apart the science of rhetoric to show Phaedrus that he has knowledge of the truth of rhetoric. ${ }^{239}$ Their conversation here imphes that they have assumed the roles of lover and beloved and are engaging in just that intellectual conversation which will lead them to Truth. In other words, Socrates shows the veracity of his depiction of the nature of the soul by applying his theory to Phaedrus. In so doing, he is leading Phaedrus, and the reader, to sympathize with the lover.

Socrates concludes his examination of rhetoric by critiquing the rhetoric used in courts of law:

[I]n the law-courts no one cares in the slightest for the truth about these things, but only for what is convincing; and this is what is probable, which is what the inan who is going to speak scientifically must pay attention to.... [S]ometimes one should not even say what was actually done, if it is improbable, but rather what is probable, both when accusing and defending, and whatever one's purpose when speaking, the probable is what must be pursued, which means frequently saying goodbye to the truth. ${ }^{240}$

Socrates is here criticizing the lawyer for sacrificing the truthful for the probable. But his own intentions are not all that different. Recall again that Socrates is not concerned with the truths of the inyths he hears, but rather what they can tell him about himself, ${ }^{241}$ this effort; in the sense that it is continuous and always changing, goes more toward probability than actual truth. Moreover, although Socrates says time and again that a philosopher is a seeker of Truth and that in order to excel in one's profession, one nnust know Truth, nowhere in the dialogue does he say that Truth is more persuasive than the probable or that, by telling the truth, the advocate will be more successful than by telling the probable.

238. See PHAEDRUS, supra note 1 , at $268 \mathrm{c}-70 \mathrm{~b}$.

239. See id. at $265 \mathrm{~d}-66 \mathrm{~b}$ (defining knowledge of a thing as the ability to take it apart and put it back together again).

240. Id. at $272 \mathrm{~d}-73 \mathrm{a}$.

241. See id. at 229e-30a; see also supra notes 60-63 and accompanying text (describing Socrates' quest for self-knowledge). 


\section{A WORD ON JUDGING AND JURY INSTRUCTIONS}

Socrates has one last myth to tell Phaedrus before they leave their resting place and head back to the city. It is the myth of Theuth and Thamus, with which Socrates argues to Phaedrus that the spoken word is superior to the written word. ${ }^{242}$ Socrates tells Phaedrus of the ancient Egyptian gods, Theuth, creator of technical inventions, and Thamus, the god-King of all Egypt, whose job it was to judge these inventions. Among his inventions, Theuth created letters and the art of writing. Theuth approached King Thamus with his invention and argued that the written word would enhance the meinories of inankind. Thamus disagreed. He concluded that written words would in fact decrease man's capacity for recollection, since man would no longer be forced to remember things but could simply refer to the written document. Thamus tells Theuth: "To your students you give an appearance of wisdom, not the reality of it; having heard much, in the absence of teaching, they will appear to know much when for the most part they know nothing." 243

This relationship between Theuth and Thamus parallels the bond between Phaedrus and Socrates. Just as Theuth offers Thamus the written word for his judgment, so too does Phaedrus offer Socrates a written document-Lysias' speech-whose style and substance he asks Socrates to critique. ${ }^{244}$ Theuth is very pleased with the art of writing as a "techne"; 245 Phaedrus likewise admires the techrical prowess of Lysias' written document, wondering if "any other Greek would have different things from these to say, which were weightier and more in number, about the same matter."246 Both Socrates and King Thamus, however, feel

242. See id. at $274 \mathrm{c}-75 \mathrm{~b}$.

243. PHAEDRUS, supra note 1 , at $275 \mathrm{a}-\mathrm{b}$.

244. See id. at $234 \mathrm{c}$. One could contend that while Theuth is proud of his writing and has in fact created it himself, Phaedrus, on the other hand, hides speeches that he himself has not even written underneath his cloak. See $i d$. at $228 \mathrm{~d}-\mathrm{e}$. This effort at concealment does not in itself indicate a disparity between Theuth and Phaedrus; rather, it shows the extent to which Phaedrus is unaware of the nature of his own soul. See GRISwOLD, supra note 5, at 30. Socrates' goal is thus expanded to reveal to Phaedrus his nature in the same way as a lover reveals to the beloved the beloved's own beauty. This revelation is necessary for Socrates to complete the conversion of Phaedrus to philosopher.

245. See PHAEDRUS, supra note 1 , at $274 \mathrm{e}$.

246. Id. at $234 \mathrm{e}$. 
that writing, while indeed eloquent and sophisticated, does more harm than good to both those who write and those who read. ${ }^{247}$

Emphasized in the myth of Theuth and Thamus is the art of judging. This is an art that Phaedrus as juror must soon master. Judging as a concept implies the idea of standing still, of not moving but of deciding upon things that are themselves moving. ${ }^{248}$ Things that are to be judged go to the judge. The judge himself inakes his decision based upon a fixed standard-the truth, the law. As such, judges are non-erotic beings: their goal is not moveinent toward Truth, but the application of the truth to the issues at hand.

In our own extended analogy, we can read the myth of Theuth and Thamus as the jury instructions that Socrates, donning moinentarily the robe of judge, is giving to Pliaedrus the juror. ${ }^{249}$ Socrates is telling Phaedrus the myth of Theuth and Thamus to guide Phaedrus in his own judgment about Lysias' written text. It is not enough for Socrates simply to tell Phaedrus what he thinks about Lysias' text. Phaedrus, who until this point has acted as witness testifying to his first hand knowledge of Lysias' text, is now the juror who must judge between Lysias' and Socrates' stories. Importantly, Phaedrus must inake his own conclusion; only when Phaedrus himself makes this determination will he truly and wholly beheve it.

With his account of Theuth and Thamus, Socrates is preparing to let go of his control over Phaedrus' persuasion. Socrates coinpares this letting go of control to the art of gardening. A gardener who truly wants a plentiful harvest will "make use of the science of farming and sow [his seeds] in appropriate soil, being content if what he sowed reached maturity in the [appropriate time].".250 Likewise, a person who truly wants another to learn and be knowledgeable will plant the seeds of wisdom in the soul of the other. Socrates describes the man wlio

247. See infra notes $259-62$ and accompanying text.

248. This, of course, refers to the ideal judge. It is the standard to which judges-and jurors-should adhere. But see Wetlaufer, supra note 18, at 1560-63 (suggesting that judges appear to be unmoving, but are moved by rhetoric nonetheless).

249. An alternative interpretation to this myth is that Socrates, as an advocate, is reviewing the judge's jury instructions before they are given. At this time, he may offer the judge his own version of what the instructions should say.

250. Phaedrus, supra note 1 , at $276 \mathrm{~b}$. 
plants and sows in [a fitting soul] words accompanied by knowledge, which are able to help themselves and the man who planted them, and are not without fruit but contain a seed, from which others grow in other soils, capable of rendering it for ever immortal, and nuaking the one who has it as happy as it is possible for a man to be. ${ }^{251}$

Throughout the dialogue, Socrates has been planting the seed in the soul of Phaedrus, hoping that this seed will bear fruit that is helpful to both Phaedrus and Socrates. Of course, it is his words of persuasion that will provide the water needed for the seeds to grow, and his desire for Phaedrus to follow him will provide the soil and warmth for them to flourish.

One last thought about judging should be inentioned. While Phaedrus, the juror, is now the judge in terms of determining the facts of the case, Plato, the author, reinains judge as to the process of the trial. That is, as author, Plato is the regulator of the dialogue, ensuring that both sides are afforded the opportunity to present their case before the jury. This may at first seem inconsistent with the argument that Plato, Socrates' student, wrote his dialogues to glorify and immortalize the wisdom of Socrates. ${ }^{252}$ There are two approaches to this seeming inconsistency that both support the theory of Plato as judge. First, it is debatable whether Plato truly admired Socrates. For instance, despite Socrates' vehement criticism of the written word, Plato wrote dialogues. In this sense, he, like Phaedrus, had to take Socrates' arguments and judge them against his own behef system. Now, in the process of presenting dialogues, he enables others to do the same. ${ }^{253}$

Second, assuming that Plato was truly Socrates' student, it would still be necessary for him to at least approach neutrality in the presentation of the two arguments. If Plato truly wants Socrates' philosophy to succeed, he must demonstrate that his

251. Id. at $276 \mathrm{e}-77 \mathrm{a}$.

252. See Introduction to PHAEDRUS, supra note 1, at 5-6 ("The degree of Plato's debt to Socrates ... is clear enough from the dialogues. . . . Plato saw his own thinking, at whatever stage, as no more than an extension of Socrates'."); West \& West, Introduction to APOLOGY, supra note 21, at 37 (suggesting that Plato's defense of Socrates against Aristophanes rescued philosophy from the poet's condemnation and created a regime in which "philosophers could live and teach").

253. See Drew A. Hyland, Why Plato Wrote Dialogues, 1 PHIL. AND RHETORIC 38, $39-40$ (1968) (arguing that the dialogue form is aporetic, see supra note 160 , and, as such, will drive its reader beyond the dialogue itself and imto a philosophic inquiry). 
arguments can withstand the most vigorous debate. And that is one purpose of the dialogues. Plato, proponent of Socrates, must be a neutral regulator in order to let the best man win.

\section{CONCLUSION: THE VERDICT}

Given the forgoing analysis, one might question whether the jury trial is the most efficacious manner of determining guilt or innocence in our society. Putting aside constitutional demands for a jury of one's peers, perhaps there are too many possible abuses of the jury system to allow for the advocacy of truth. That is, if one persuades a juror, or an entire jury, by identifying with that jury and creating a sense of kinship, or empathy, if one persuades not by telling the truth but by using the truth to make one's side look as much like the truth as possible, if one persuades by relying on emotions and behefs rather than on scientific or logical facts, is that persuasion really "fair"? Given that the jury is, in its deliberations, a mysterious entity, completely independent once it enters the deliberating room, it is impossible for us ever to be certain that the jury has in fact reached a truthful verdict-if such a verdict is possible. These uncertainties suggest that perhaps our system of justice would be better served if, instead of jurors, we rehied exclusively on judges, who are at least theoretically nonerotic, not susceptible to persuasion, and who would decide only on facts and not on emotion.

Of course, our current jury system has tried to resolve these issues. The formal requirements of a jury trial serve to ensure that no litigant has a disproportionate advantage. Any person can sue, regardless of status or wealth. ${ }^{254}$ Every person is judged by either a jury of his peers or a neutral factfinder. ${ }^{255}$ Every attempt is made to remove bias or emotion from that judgment. ${ }^{256}$

A jury may be told time and again to base its decision on the law as apphed to the facts of the case. However, it is utterly im-

254. See, e.g., Bounds v. Smith, 430 U.S. 817, 821-22 (1977) (asserting the fundament constitutional right of access to the courts for prisoners).

255. See U.S. CONST. amend. VII ("In Suits at common law, ... the right of trial by jury shall be preserved .....").

256. Indeed, if a judge finds that a verdict is based on emotion rather than evidence, she has the power of remittitur to reduce it. See, e.g., Blunt v. Little, 3 F. Cas. 760 (1822) (holding that judicial review of the size of punitive damages is a sufficient safeguard against excessive awards). 
possible to remove emotions from that decision-and both attorneys and clients realize that fact. Within limits, ${ }^{257}$ every attempt is made to play to those emotions, from voir dire all the way through to the rendering of the verdict. ${ }^{258}$ Drama, humor, anger, tears-all are ploys to encourage the juror to side with one party and not the other. In this way, there is no difference at all between Socrates' persuasion of Phaedrus and an attorney's persuasion of the jury.

However, although these issues remain serious, an alternative interpretation of our jury system exists. Even as Socrates' persuasion of Pliaedrus mirrors the problems that are inevitable in our jury system, the fact that Plato wrote the dialogues suggests that those problems may be necessary to the pursuit of a different, perhaps higher, goal for the jury system. In the Phaedrus, Socrates criticizes the written word, claiming that it is not a tool for recollection but will rather lead to forgetfulness. ${ }^{259}$ Moreover, Socrates compares the written word to a painting which lies vulnerable to any interpretation once it has left the lands of its painter. ${ }^{260}$ As he tells Pliaedrus, "The offspring of painting stand there as if alive, but if you ask them something, they preserve a quite solemn silence." ${ }^{261}$ Written words are similarly indeterminate:

[Y]ou might think that they spoke as if they had some thought in their heads, but if you ever ask them about any of the things they say out of a desire to learn, they point to just one thing, the same each time. And when once it is written, every composition is trundled about everywhere in the same way, in the presence both of those who know about the subject and of those

257. See WRIGHT, supra note 38, at 258-59. A lawyer crosses over the line into unethical behavior if she argues that a jury act upon emotion and not upon evidence. "An argument must have some relationship to the evidence and it must also be free from inflammatory remarks." Id. at 258. See also Louisiana \& Arkansas Ry. Co. v. Capps, 766 S.W.2d 291, 294-95 (Tex. Ct. App. 1989) (holding that argument to the jury must be "confined strictly to the evidence" and must be free of personal criticism of opposing counsel); LUBET, supra note 132, at 429 (noting that since false emotion is too easily seen through, lawyers should save it for their discussion of the moral dimension of their case).

258. See, e.g., James Alexander, A BRIEF NARRATive of the Case AND Trial OF JOHN PETER ZENGER, 23-26 (Stanley Nider Katz ed., 1963) (narrating how Zenger's attorney eloquently persuaded the jury to disregard the law in order to acquit his client based on the jury's sense of right).

259. See PHAEDRUS, supra note 1 , at 275 a.

260. See id. at $275 \mathrm{~d}-\mathrm{e}$.

261. See id. at $275 \mathrm{~d} 5-7$. 
who have nothing at all to do with it, and it does not know how to address those it should address and not those it should not. When it is ill-treated and unjustly abused, it always needs its father to help it; for it is incapable of defending or helping itself. $^{262}$

But Plato has included this argument in a written dialogue. Clearly he sees soine advantage to writing that would defeat or circumvent Socrates' argument or would be worth the risks that Socrates has described. Perhaps the importance of the Platonic dialogue lies not in the truth itself, but in the process of discovering the truth. In the Phaedrus, Socrates describes the dialectical process of discovery that the lover and the beloved experience in their intellectual conversations. It is Plato, however, who actually offers his readers such an intellectual conversation. By writing a dialogue, he provides thein with a conversation coinplete with a setting, history, and influential circumstances. Although Plato is not directly conversing with his audience, lie is offering conversation to then. Moreover, he is encouraging them to converse with each other and to pursue the truth through conversation. It is this process, and not its origin in the truth, that makes the Platonic dialogues both lasting and umique.

The jury trial, with all its faults, may be defensible on similar grounds. Like Plato, attorneys create stories through conversation. In a trial, the conversation jurors hear is the interplay between attorney and witness, client, and judge. That conversation also includes the rhetorical, one-sided address each attorney makes to the jury at the open and close of every trial. After both attorneys have presented their cases and the judge has offered his instructions, the jury must collectively discuss who should win and who should lose. They sift through the evidence, weigh the arguments, and question each other. Some conversations are easy, others are strenuous; some are friendly, others angry. Some conversations take minutes before agreement is reached, others days, and still others never reach resolution. This conversation is, im effect, the very same conversation that Plato anticipated for the readers of his dialogues.

For Plato, the attainment of the truth is to a great extent not in the control of those who strive for it. Two people can seek the

262. Id. at $275 d-e$. 
truth if they are in love. But, as shown in the Phaedrus, people cannot seek out Love. Love inust strike them by surprise, and even if it does, the conversants must be very fortunate to receive a clear vision of Truth in their struggle to reach beyond the heavens.

But this can never happen if individuals do not engage in philosophical conversation. Questioning and criticizing the Platonic dialogue is itself part of that process. Within the dialogue, Plato has complete control over what Socrates says and whether Phaedrus beheves him. In much the same way, while he is guiding Phaedrus in conversation, Socrates has considerable control over Phaedrus, even at the very moinent in which he apparently surrenders this control. But Plato does not have this same control over his reader. To this extent, the dialogue is about both maintaining control and about letting go of that control.

This Platonic "letting go" is crucial to the process of conversation. At some point, an advocate must end his argument and let the listener respond. In that instant, the advocate has lost control. But in that same instant, the process moves from a one-sided exposition to a conversation that grows as the histener ponders the argument and queries the facts. Plato was willing to let go of his control over his listener in order to let such a moinent occur. In this moment, thought is developed and expanded. Without this loss of control, there would be only tyranny.

The moinent of release is the same moinent that occurs when the lawyers have concluded their arguments, the judge has given the jury its instructions, and the jury is sent to deliberate. In this loss of control hes the conversation that allows our jury system to grow, expand, and flourish. Far from being arbitrary or capricious, far from being vindictive or resentful, the jury serves to continue our progress toward the truth. Whether or not the verdict im eacls particular case coinports with the factual truth of what really happened, the process of histening to the arguments, of talking amongst theinselves, of debating, of fearing, of questioning, of agreeing, of being pulled one way and then the other, is what makes the jury system so important. Without it, there would be nothing but tyranny, tyranny of the law, tyranny of the facts. To be sure, laws and facts can never tell us as much about ourselves as we can learn from each other. 